\title{
Restricting Freedom of Expression for Religious Peace: On the ECHR's Approach to Blasphemy
}

\author{
Eva Hauksdóttir \\ Independent researcher, Reykjavík, Iceland \\ eva@lausnir.is
}

\begin{abstract}
The ECtHR's ruling in ES v Austria raises questions about the Court's methodology in blasphemy cases. The ECtHR interprets Article 9 of the Convention as including a right to respect for religious feelings and presumes that 'justified indignation' may disrupt 'religious peace'. Therefore, expression counting as 'gratuitously offensive' to religious feelings is not granted protection under Article 10. Es $v$ Austria reveals certain problems that arise when criticism of religion is driven by hatred and when religious insult merges with political criticism. This article argues that Strasbourg's approach to blasphemy increases uncertainty about the boundaries of free speech. The terms 'religious feelings' and 'religious peace' are scrutinised, and the political context of $E S v$ Austria analysed. It concludes that by failing to distinguish clearly between blasphemy and incitement to hatred, and by upholding the criminalisation of questioning the Prophet Muhammad's morals, the Court has jeopardised freedom of expression in Europe.
\end{abstract}

\section{Keywords}

Articles 9 and 10 ECHR - ES v Austria - religious peace - religious feelings - gratuitously offensive expression - freedom of expression - religious freedom 
On 15 October 2018, the European Court of Human Rights (ECtHR) ruled on the case of Es $v$ Austria. ${ }^{1}$ The Court concluded, unanimously, that criminalising allegations of Prophet Muhammad being a paedophile did not violate freedom of expression under the European Convention on Human Rights (ECHR). The limitation is justified on grounds of the necessity to protect the feelings of others and on the state's right and duty to preserve religious peace in Austria. The ruling in $E S$ raises many questions concerning the interplay of Articles 9 and 10 of the Convention. One curious thing is the presumption that political speech that does not incite hatred is nevertheless perceived as a threat to religious peace. Another thing that seems peculiar is that the Court considered laws aimed at incitement to hatred to be relevant, even though Austrian courts had dismissed allegations of incitement. Furthermore, the ruling raises concerns about the risk of religious rights being used as a means of suppressing debates on important social topics, including sexual abuse and other matters that must be discussed in a democratic society.

Since 1991 the ECtHR has ruled on several cases concerning restrictions on freedom of expression on grounds of disparagement of religious doctrines, religious insults or defamation of religion (hereafter blasphemy cases). The terminology used in the case law is evasive and while many member states are moving towards the abolition of blasphemy law, Strasbourg has endorsed restrictions on blasphemy, mainly on two grounds: the right of others to respect for their religious feelings under Article 9 of the Convention; and states' right and duty to uphold religious peace.

What is the meaning of 'religious peace' under Strasbourg's jurisdiction? ${ }^{2}$ Seemingly the term has a far broader meaning than the absence of violent conflict. Drawing upon the case law, religious peace manifests in the peaceful coexistence of all religions and other belief systems, that is, the followers' mutual tolerance of each other's convictions and customs. ${ }^{3}$ One of the premises for peaceful coexistence is that those who exercise their freedom to criticise religions avoid being 'gratuitously offensive' to the religious feelings of

$1 \quad$ ES v Austria 3845o/12 (ECtHR, 25 October 2018).

2 The term 'religious peace' appears in many judgments, see eg, Otto-Preminger-Institut $v$ Austria 13470/87 (ECtHR, 20 September 1994) para 56.

3 See eg, Kokkinakis $v$ Greece 14307/88 (ECtHR, 25 May 1993) para 33 and sAs v France [GC] 43835/11 (ECtHR,1 July 2014) para 126 on the necessity for limitations on the freedom to manifest religion and believes in societies where several religions coexist. 
others. ${ }^{4}$ Thus, expression that is likely to spark 'justified indignation' is liable to jeopardise religious peace and can be restricted on the grounds of the 'rights of others' under Article 10(2). ${ }^{5}$ However, Article 9 does not mention any right to respect for religious feelings and if that premise for religious peace lacks justification, it may be necessary for the ECtHR to reconsider its approach to blasphemy.

This paper deals with the ECtHR's justifications for upholding the states' restrictions on blasphemy. The literature on the ECtHR's notion of 'religious peace' is scarce. I have not found a single article that offers a broad discussion on religious peace and peaceful coexistence under Strasbourg's jurisprudence and the case law does not provide clear answers about the meaning and scope of the term. In contrast, restrictions on blasphemy on grounds of religious feelings have been scrutinised. As religious peace rests on respect for religious feelings, these writings may shed light on the Court's premises for endorsing the criminalisation of blasphemy.

In academic analyses of the case law, two perspectives are weighed against each other. On one hand, the importance of freedom of expression as a human rights principle and as a cornerstone of a thriving democracy. ${ }^{6}$ On the other, the duty of a pluralistic and tolerant society to avoid double standards and protect minorities from abuse and hostility. ${ }^{7}$ The literature reveals concerns about the ECtHR's conduct of balancing freedom of expression against religious feelings. Susannah Vance argues that, although religious hatred must be penalised, restrictions on blasphemy require better justifications than religious feelings. ${ }^{8}$ Similarly, Jeroen Temperman emphasises that abusive expression should be assessed on grounds of advocacy of religious hatred, not the targets' feelings. ${ }^{9}$

The Court often uses the wording 'gratuitously offensive' about blasphemy or vulgar expression on religion. See eg, Giniewski v France 64016/oo (ECtHR, 31 January 2006) para 43 .

5 The term 'justified indignation' frequently occurs in ECtHR blasphemy cases, see eg, Otto-Preminger-Institut v Austria (n 2) para 48.

6 E Howard, 'Gratuitously Offensive Speech and the Political Debate' (2016) 6 European Human Rights Law Review 636.

7 Although not concerned with Europe, Meital Pinto provides arguments for restricting verbal offences of minorities, on grounds of their cultural integrity, rather than religious feelings, see, M Pinto, 'What Are Offences to Feelings Really About? A New Regulative Principle for the Multicultural Era' (2010) 30(4) Oxford Journal of Legal Studies 695. Convention Principles' (2004) 14 Transnational Law and Contemporary Problems 201.

9 J Temperman, 'Blasphemy, Defamation of Religions and Human Rights Law' (2008) 26 Netherlands Quarterly of Human Rights 517. 
Ian Leigh argues that the ECtHR has granted the states too wide a margin of appreciation. ${ }^{10}$ Ilias Trispiotis criticises the Court for upholding restrictions on blasphemy without considering if less restrictive measures were available. ${ }^{11}$ Some scholars, such as Aoife O'Reilly ${ }^{12}$ and Ian Cram, suggest that supressing offensive speech may be counterproductive and increase antipathy towards marginalised minorities. ${ }^{13}$

Drawing upon Strasbourg's case law and relating literature, my aim is to answer the following question: Does the ECtHR's approach to protection of religious peace jeopardize freedom of expression in Europe? As the Court's notion of religious peace rests on religious feelings, I will scrutinise the legitimacy of granting protection of religious feelings the status of a human right. I will examine how that approach affects the notion of religious peace, especially with respect to Muslim sensitivities. Although religious hatred must be discussed to some extent, my focus is on blasphemy; the limits of expression ranking as incitement are outside the scope of this article.

The paper consists of four main sections. Section 2 discusses the freedoms of Articles 9 and 10 of the Convention and some problems that arise, when criticism of religion overlaps with political message. Section 3 examines the terminology applied to blasphemy cases under Strasbourg's jurisprudence and questions the legitimacy of protecting religious feelings. Section 4 discusses the concept 'religious peace', examines how conflicts between religious sensitivities and free speech are treated by the Court and explores the relevance of justified indignation and religious hatred to blasphemy cases. Section 5 covers the political context of ES $v$ Austria and criticises the ECtHR's approach, its reasoning and conclusions. Concluding that in $E S v$ Austria the ECtHR endorsed a highly controversial approach to preserve religious peace, I finally make suggestions on how religious tensions should be addressed with the aim of protecting freedom of expression in Europe.

10 I Leigh, 'Damned if They Do, Damned if They Don't: The European Court of Human Rights and the Protection of Religion from Attack' (2011) 17 Res Publica 55.

11 I Trispiotis, 'The Duty to Respect Religious Feelings: Insights from European Human Rights Law' (2013) 19 Columbia Journal of European Law 499. A O'Reilly, 'In Defence of Offence: Freedom of Expression, Offensive Speech, and the Approach of the European Court of Human Rights' (2016) 19 Trinity College Law Review 234.

13 I Cram, 'The Danish Cartoons, Offensive Expression and Democratic Legitimacy' in Extreme Speech and Democracy, I Hare and J Weinstein (eds), (Oxford University Press 2009) 311 . 
Despite being essentially complimentary of each other, freedoms of expression and religion often collide. Criticism of religions often sparks outbursts among believers who accuse the critics of abusing their freedom of expression. Free speech defenders then accuse offended believers of advocating censorship. The ECtHR has acknowledged the need to preserve religious peace, and on those grounds endorsed restrictions on blasphemy. Aiming to shed light on which kind of religious insults are considered liable to arouse justified indignation, this section outlines the conflicting freedoms of Articles 9 and 10 of the Convention, the Court's methodology and some of the problems that arise, when criticism of religions overlaps with political message.

\subsection{Compatible Freedoms}

All fundamental human rights instruments provide for freedom of thought, conscience and religion, as well as freedom of expression. These freedoms are enshrined in Article 9 and 10 of the ECHR. Freedom of religion, granted under Article 9, includes the right to manifest one's religion or belief, and to change it. Freedom of expression under Article 10 includes a right 'to hold opinions and to receive and impart information and ideas without interference by public authority'. Limitations to both freedoms must be prescribed by law, be necessary in a democratic society and serve a legitimate aim.

The text of the Convention supports the interpretation that under the ECHR, freedom of expression does not need a justification, whereas restrictions and limitations must be supported by one or more of the interests listed in Article $10(2) \cdot{ }^{14}$ It is undisputed within the world's most influential human rights bodies that restrictions on freedom of expression must be applied with caution. The UN Human Rights Committee has declared that 'when a State party imposes certain restrictions on the exercise of freedom of expression, these may not put in jeopardy the right itself. ${ }^{15}$ The ECtHR has repeatedly stated that the need for any restriction must be 'convincingly established.' ${ }^{6}$ Even expressions that may 'shock, offend or disturb' are protected to a great extent under Article 10 of the Convention, on the premise that '[s] uch are the

\footnotetext{
14 K Lemmens, “Irreligious" Cartoons and Freedom of Expression: A Critical Reassessment' (2018) 18 Human Rights Law Review 89,102.

15 UN Human Rights Committee (UnHRC), 'General Comment No. 34, Article 19: Freedoms of Opinion and Expression', $C C P R / C / G C / 34,12$ September 2011, para 21.

16 See eg, Observer and Guardian $v$ the United Kingdom, 13585/88 (ECtHR, 26 November 1991) para 59 and Oberschlick $v$ Austria (No 2) 20834/92 (ECtHR, 1 July1997) para 29.
} 
demands of that pluralism, tolerance and broadmindedness without which there is no 'democratic society".17 Free speech is not only a precious individual right, democracy cannot thrive unless new information and conflicting views can be expressed, received and debated. This also applies to extreme viewpoints, as public airing creates opportunities to challenge ideas that contradict democratic values. ${ }^{18}$ Furthermore, without a right to criticise those in power, oppression is to be expected. For these reasons, freedom of expression has been described as one of the essential foundations of democracy, deserving great protection and narrow limitations. ${ }^{19}$ This freedom, however, is not an absolute right under any international instrument. There is a universal consensus that it does not include a right to harm others. There are no NGO s fighting for the right to commit a perjury or give false information about the content of medicines. On the other hand, restrictions on expression about religious matters have been harshly criticised in the Western world in recent decades. The European trend is towards the abolition of blasphemy law. Since 2015, five European states have decriminalised blasphemy. ${ }^{20}$

Despite being an independent human right, freedom of thought, conscience and religion under Article 9, overlaps with freedom of expression. According to Kevin Boyle, both rights are the offspring of resistance to religious fundamentalism, in the sense that the opposition to religious absolutism in Europe paved the way for an open discussion on political topics. ${ }^{21}$ Freedom of thought is included in freedom of expression, and the right to manifest religion, and other ideology, is in principle a right to express thoughts. Excessive limitations on expression may render the freedom of thought void, as new information and criticism are often the premise for forming and changing opinions. Then why does the ECtHR see these freedoms as conflicting rights that must be

Handyside $v$ the United Kingdom [GC] 5493/72 (ECtHR, 7 December 1976) para 49.

C George 'Hate Spin: The Twin Political Strategies of Religious Incitement and OffenseTaking' (2016) 27 Communication Theory 156, 159 .

Bodies of the Council of Europe, including the ECtHR, have repeatedly referred to freedom of expression as an essential foundation of a democratic society, see eg, European Commission for Democracy Through Law (Venice Commission), 'Report on the Relationship between Freedom of Expression and Freedom of Religion: The Issue of Regulation and Prosecution of Blasphemy, Religious Insult and Incitement to Religious Hatred' (adopted by the Venice Commission at its 76 th Plenary Session, 17-18 October 20o8) para 34 .

R Kahn, 'Five Thoughts about the Repeal of Denmark's Blasphemy Ban' (conference paper, Loyola Constitutional Law Colloquium, 29 January 2018): <https://www.researchgate.net/ publication/322774029_Five_Thoughts_about_the_Repeal_of_Denmark's_Blasphemy_ Ban>.

K Boyle, 'The Danish Cartoons' (2006) 24 Netherlands Quarterly of Human Rights 185, 188. 
balanced ${ }^{22}$ In my opinion the answer lies in too broad an interpretation of religious rights.

\subsection{The Balancing Exercise}

Of the interests listed in Article 10(2) that may justify limitations on freedom of expression, the one most relevant to blasphemy cases is the protection of the reputation or rights of others'. Public order is often mentioned in a passing, but the Court has not relied on 'public safety' and 'prevention of disorder or crime' in restricting blasphemy. ${ }^{23}$ The ECtHR interprets 'responsibilities' and 'protection of the rights of others' in Article 10(2) as a duty to convey one's thoughts in a manner that is not gratuitously offensive to others. This does not only apply to expression about religion; similar wording is used in cases where freedom of expression is weighed against the right to reputation. It is, however, noted that this reason for restriction may be legitimate 'in the context of religious opinions and beliefs' ${ }^{24}$ and it is particularly noticeable in blasphemy cases. ${ }^{25}$

Scholars who agree that freedom of religion and expression are intertwined rather than opposites, nevertheless come to different conclusions on whether these rights need to be balanced. Kevin Boyle notes that since there is no hierarchy of convention rights, freedom of expression does not trump religious rights, and that a pluralistic society calls for adjusting to changes in religious practises and expectations. ${ }^{26}$ Others argue that since the ECtHR's authority is limited to interpreting Convention rights, it is inappropriate to balance freedom of expression against a right that is not mentioned in the ECHR, that is, the right not to be offended. In such instances the Court should interpret 'the rights of others' narrowly. ${ }^{27}$ Trispiotis claims that the balancing exercise, 'adds fuel to a pseudo-debate between free speech and respect for everyone's religious beliefs. ${ }^{28}$ Erica Howard points out that the freedom to criticise belief systems serves religious rights under the ECHR as ' $[t]$ he freedom to change one's

ECtHR, 'Freedom of Expression and Respect for Religious Beliefs: Striking the Right Balance' Thematic Factsheet (July 2018): <https://rm.coe.int/factsheet-on-freedomof-expression-and-freedom-of-religion-june2018-do/168o8c168c $>$.

23 Article 10 ECHR.

24 Otto-Preminger-Institutv Austria (n 2) para 49.

25 See eg, Palomo Sánchez and Others v Spain [GC] 28955/o6 (ECtHR, 12 September 2011). The state used the wording 'gratuitously offensive' and the Court upheld the state's reasoning. Expressions in libel cases are often described as 'unduly insulting' or 'gratuitous personal attack'. See, ECtHR, 'Protection of Reputation' Factsheet (March 2019): <https://www.echr. coe.int/Documents/FS_Reputation_ENG.pdf>.

26 Boyle (n 21) 188.

$27 \quad$ O'Reilly (n 12$) 246$.

28 Trispiotis (n 11$) 502$. 
religion would be meaningless if one could not receive or impart views that criticise or deny the tenets of one's religion or support those of another religion.29 Paul Sturges takes a similar stand: 'Dignity in the defence of one's views involves the potential for dignified withdrawal from a position that proves indefensible. ${ }^{30}$ Temperman argues that in blasphemy cases, ruled in favour of the states, the Court has failed to explain how the impugned expressions might have restricted believers' liberty to thought, conscience and religion. ${ }^{31}$ Leigh points out that the Court has not treated campaigns intended to warn against religious cults or 'de-programming' of their members as interference with their freedom under Article $9 .{ }^{32}$ If a right to respect for religious feelings exists, it must apply to members of all belief systems, also to fundamentalists.

In recent decades, conflicts between liberal ideas about free speech and Islam's strict view on blasphemy have been prominent in Europe. In 2005, a Danish newspaper published 12 cartoons representing Muhammad or Islam. Muslims clearly saw the publication as a political statement and protests were not just aimed at the Danish media but also at Western embassies and cultural institutions. The publisher claimed that the initiative was aimed at countering self-censorship. The publisher's motives and understanding of self-censorship have been questioned, ${ }^{33}$ but freedom of the press is essentially a political matter. This is just one example; in the West, blasphemy of Islam has become a political issue, both as a measure to promote Islamophobia and as a reaction to perceived demands for censorship. Although the Danish cartoon affair and similar controversies have not been tried at Strasbourg, large scale conflicts between free speech advocates and Muslims may have affected both the Convention's member states' and the ECtHR's approach to blasphemy.

\subsection{Strasbourg's Approach in Restricting Blasphemy}

One of the problems with blasphemy cases is that restrictions based on religious feelings collide with the great protection that political expression is granted under the Convention. Political speech has been defined as including, 'all speech relevant to the development of public opinion on the whole range of issues which an intelligent citizen should think about.'34 This clearly

\footnotetext{
29 Howard (n 6) 639.

$30 \quad$ P Sturges 'Limits to Freedom of Expression? The Problem of Blasphemy' (2015) 41(2) International Federation of Library Associations and Institutions 112, 115.

$31 \quad$ Temperman (n 9) 541.

$32 \quad$ Leigh (n 10) 65 .

33 R Kahn, 'Flemming Rose, the Danish Cartoon Controversy, and the New European Freedom of Speech' (2010) 40 California Western International Law Journal 253. Howard (n 6) 639, citing E Barendt.
} 
encompasses expressions about religion and belief. On this basis, Cram argues for strong protection of criticism of Islam, referring to 'overt desire of certain Islamic groups to attain political power so that they might advance their goal of creating a theocratic state' ${ }^{35}$ Whether such a goal exists is out of the scope here, but it cannot be overlooked that disputes concerning religion often have political dimensions. The case of Es $v$ Austria $^{36}$ is such an example, and it is quite possible that the ECtHR ruling may have a chilling effect on political debates about the influence of religion on child marriages and other heated topics that may concern the human rights of others. Suppressing debate on revered literature and religious practices, on the grounds that the followers find it offensive, is not in line with the broad definition of political expression.

\subsubsection{The Court's Methodology}

To determine whether an interference with freedom of expression is justifiable, the ECtHR applies a three-part test. First, the interference must be prescribed by law. Secondly, it must serve a legitimate goal in accordance with Article 10(2). Thirdly, it must be necessary in a democratic society. In assessing this third criterion, the Court considers whether there is 'a pressing social need' for the restriction. ${ }^{37}$ To this end, the Court applies the Handyside formula, meaning: first, that a democratic society tolerates not just criticism but also expressions that may 'shock, offend or disturb'; secondly, the expression must be compatible with 'pluralism, tolerance and broadmindedness'. ${ }^{38}$ In all legal cases, context is essential, and in blasphemy cases the Court considers the circumstances, the venue and manner in which the message is conveyed. Most importantly, it assesses whether the disputed expression counts as a contribution to a democratic society. ${ }^{39}$

The Court distinguishes between different categories of expression, based on the necessity for such expression to thrive in a democratic society. Political speech is granted the highest level of protection as the right to criticise policies and those who hold power is considered essential to prevent oppression. Expression of artistic and cultural nature enjoys less protection and the greatest restrictions are tolerated on expression that mainly serves commercial purpose. These categories overlap. It can be questionable when art carries a political message and when it is outright defamatory. The prevailing ethos is

$35 \quad \operatorname{Cram}(\mathrm{n} 13) 323$.

$36 \quad$ Es v Austria (n 1$)$.

37 Otto-Preminger-Institut $v$ Austria (n 2 ) para 52.

$38 \quad$ Handyside $v$ the United Kingdom (n 17) para 49.

39 E Barendt, Freedom of Speech (Oxford University Press 2010) 65 . 
relevant too, it can be disputable whether an erotic piece is of artistic value or simply pornographic, hence subjected to the restrictions posed on commercial expression. ${ }^{40}$

In blasphemy cases, the ECtHR estimates whether the impugned expression is perceived as a contribution to a public debate or if the applicant has exceeded their freedom of expression by being gratuitously offensive. ${ }^{41}$ The Court also acknowledges each state's right and obligation to apply the law to protect 'religious peace' in its territory. ${ }^{42}$ Ever since the ECtHR's first blasphemy case, the 1993 Otto-Preminger-Institut $v$ Austria judgment, ${ }^{43}$ the member states have enjoyed a wide margin of appreciation in these matters, as domestic courts are in a better position than the ECtHR to evaluate sensitivities and religious tensions in their territory. ${ }^{44}$

\subsubsection{Religious Insult or Political Criticism?}

When does offensive expression on religion count as political criticism and when as an insult apt to raise 'justified indignation'? The case law sheds light on these contrasts.

In Otto-Preminger there was no political context: apparently the filmmakers' purpose was to provoke Christian perception of sacred figures and it was done in a denigrating manner. ${ }^{45}$ The same applies to Wingrove $v$ the United Kingdom, which concerned a film where Jesus was the subject of sexual fantasies. ${ }^{46}$ In ÍA $v$ Turkey, the applicant had written a novelistic style book where he expressed philosophical and theological views. Political criticism is not mentioned in the judgment. The Court agreed that the book included an abusive attack on Muhammad. ${ }^{47}$ In none of these cases did the Court find a violation of Article 10.

By contrast, the political context was significant in Aydin Tatlav $v$ Turkey. ${ }^{48}$ The applicant had criticised Islam for endorsing social injustices. The ECtHR held, unanimously, that the state's interference constituted a violation of

B Rainey, E Wicks and C Ovey,Jacobs, White, and Ovey. The European Convention on Human Rights (7th edn, Oxford University Press 2017) 483-516.

See eg, Otto Preminger-Institut v Austria (n 2) para 49, Wingrove v the United Kingdom 17419/9o (ECtHR 25 November 1996) para 52 and Es $v$ Austria (n 1) para 35.

Otto-Preminger-Institut $v$ Austria (n 2) paras $5^{2}$ and 56.

Otto-Preminger-Institut v Austria (n 2).

On the margin of appreciation in blasphemy cases, see, Leigh (n 10).

Otto-Preminger-Institut $v$ Austria (n 2).

Wingrove $v$ the United Kingdom (n 41).

IA v Turkey 42571/98 (ECtHR, 13 September 2005).

Aydın Tatlav v Turkey 50692/99 (ECtHR, 2 May 2006). 
Article 10.49 Giniewski $v$ France concerned an article where the author asserted that some doctrines of the Catholic Church might have inspired the Holocaust. ${ }^{50}$ The Court held that historical criticism supported by evidence did not count as gratuitously offensive. ${ }^{51}$ In Klein $v$ Slovakia the applicant had criticised the Archbishop for promoting censorship and consequently been convicted of disparaging the Archbishop and thereby the members of the Catholic Church (as the clergy was their representative). ${ }^{52}$ Despite being offensive, the article was solely aimed at the Archbishop and considering the political context the Court concluded that Article 10 had been violated. ${ }^{53}$

Given the significance of the political context in these cases, it seems remarkable that in $E S$ the ECtHR did not mention protection of political speech. The Court concluded that the domestic courts had carefully balanced freedom of expression with the right to protection of religious feelings.

\section{3}

\section{Religious Feelings}

Under Strasbourg's jurisdiction, the precursor to a disturbance of religious peace is 'justified indignation'. On those grounds the ECtHR presumes that religious feelings must be protected. This section argues that defining the 'rights of others' under Article 10(2) in terms of religious sensitivities is a slippery slope. Both because the uniqueness of religious feelings is questionable and because there exists no clear distinction between religions, other belief systems and political philosophy. If there is no justification for protecting religious feelings under the Convention, then the concept 'religious peace' has been interpreted too broadly.

\subsection{Terminology Applied to Religious Offences}

The terms applied to religious offences in European states lack clarity and uniformity. There exists no internationally harmonised definition of the term 'blasphemy', but the Council of Europe (CoE) Committee on Culture, Science and Education defines blasphemy as 'the offence of insulting or showing contempt or lack of reverence for god and, by extension, toward anything considered

\footnotetext{
49 Ibid. See, especially para 28 on the Court's reasoning.

50 Giniewski (n 4).

$51 \quad$ Ibid para 53 .

$5^{2} \quad$ Klein v Slovakia 72208/o1 (ECtHR, 31 October 2006).

53 Ibid paras $55^{1-55}$.
} 
sacred'.54 Relying on an examination on European states' blasphemy laws, the Venice Commission observes that:

[w] hile there is no general definition of "religious insult", the relevant European provisions appear to cover the different (often at the same time) of "insult based on belonging to a particular religion" and "insult to religious feelings". 55

A study done for the $\mathrm{CoE}$, in the wake of the reactions to the Danish cartoons, described three types of religious offences; blasphemy, religious insult and religious hatred. ${ }^{56}$ In domestic legislation and case law, these concepts merge and overlap. In addition, some jurisdictions include terms like 'disparaging of religious doctrines', 'defamation of religion', 'blasphemous libel' and 'religious hatred'. Presumably, the term 'defamation of religion', used in a series of non-binding resolutions, accepted by the UN General Assembly in 20012010,57 is synonymous with religious insult and covers various manifestations of criticism and contempt towards religions.

The ECHR does not mention hatred. Nevertheless the ECtHR holds that since respect for human dignity is an inherent part of a democratic society it may, as a matter of principle, be necessary 'to sanction or even prevent all forms of expression which spread, incite, promote or justify hatred based on intolerance .... ${ }^{58}$ This understanding is consistent with Article 20 of the International Covenant on Civil and Political Rights (ICCPR) which stipulates that 'any advocacy of national, racial or religious hatred that constitutes incitement to discrimination, hostility or violence shall be prohibited by law. 59

There are no clear boundaries between these categories. As a rule of thumb, 'blasphemy' is an insult to anything considered sacred, whereas 'religious insult' is directed at the members of the religion and/or their religious feelings. Religious hatred is more aggressive and may or may not be intended to incite discrimination or violence against the believers. ${ }^{60}$

54 'Report on the Relationship between Freedom of Expression and Freedom of Religion ...' (n 19) para 24.

Ibid para 28.

Ibid paras 22-34.

Center For Inquiry 'Dissident Denied: A Survey of Global Blasphemy and Incitement Laws \& Cases' (2013): <https://centerforinquiry.org/docs/cfe/dissent_denied.pdf $>2$.

58 ECtHR, 'Hate Speech' Factsheet (September 2020), citing Erbakan v Turkey 59405/00 (ECtHR 6 July 2006) para 56: <https://www.echr.coe.int/documents/fs_hate_speech_eng. pdf $>$.

59 Article 20 International Covenant on Civil and Political Rights (adopted 16 December 1966, entered into force 23 March 1976) 999 UNTS 171 (ICCPR).

$60 \quad$ Leigh (n 10) 57 . 
It is unclear whether or not the blasphemy definition cited above requires mens rea but the Parliamentary Assembly of the Council of Europe (PACE) recommends that 'national law should only penalise expressions about religious matters which intentionally and severely disturb public order and call for public violence. ${ }^{61}$ However, a discourse that believers perceive as blasphemous, like political criticism or a joke, may be uttered without intent to hurt. This situation is quite plausible in a community where groups of immigrants from societies founded on Islamic law and ethics are exposed to a culture of vulgar caricature, satire and grotesque humour that holds nothing sacred. Moreover, criticism aimed towards culture or cultural sects or institutions may be perceived as an attack on religion. Sturges suggests a more accurate definition of blasphemy as:

... perceived disparagement of a god or gods, prophets and messiahs, the texts and physical copies of religious books, beliefs and practices associated with religion, religious sites and structures, and probably various other connected objects of reverence. ${ }^{62}$

The keyword here is perceived, the offence is in the eye of the beholder. It is not always predictable whether expression will be perceived as offensive.

Can the criminalisation of a perceived insult be justified? When dealing with a relatively benign joke, the mens rea may be absent and sentencing a person, solely on the grounds of perception, would violate the rule of law. Comments made under the auspices of a political party, whose main goal is opposition to immigration, are obviously of a different nature than an innocent joke and the intent to hurt or provoke seems obvious. The comments made by Es on Prophet Muhammad's relationship with his young wife Aisha were perceived as an insult - and - if not intended as insult, at least that perception was predictable. Nevertheless, that blasphemous criticism touched upon a real problem - which should be discussed in a democratic society - and criticising the Prophet or his status as the perfect example, is always perceived as an insult to Muslims.

\subsection{Historical Understanding of Blasphemy}

The right to protection of religious feelings was established under the ECHR in Otto-Preminger, where the 'rights of others' protected under Article 10(2)

$61 \quad$ Parliamentary Assembly of the Council of Europe (PACE), Recommendation 1805(2007) on 'Blasphemy, Religious Insults and Hate Speech against Persons on Grounds of their Religion', Rapporteur: Mrs Sinikka Hurskainen (adopted 29 June 2007, 27th sitting) para 15. 
were interpreted in light of Article $9 .{ }^{63}$ The case concerned the seizure of a film where key figures of Christianity were depicted as stupid or immoral. The ECtHR referred to 'respect for the religious feelings of believers as guaranteed in Article 9. ${ }^{64}$ Interestingly, Article 9 does not mention such a right. As the dissenting Judges in this case noted:

The Convention does not, in terms, guarantee a right to protection of religious feelings. More particularly, such a right cannot be derived from the right to freedom of religion, which in effect includes a right to express views critical of the religious opinions of others. ${ }^{65}$

The dissenting Judges, however, acknowledged that believers' feelings might be protected under the Convention to some extent, since 'violent and abusive attacks on the reputation of a religious group' might infringe their right under Article 10). ${ }^{66}$ Apparently, this interpretation draws upon the right to reputation. The majority's approach is far more problematic. It is difficult to assess feelings and neither religious groups nor other cultural groups are homogeneous. Moreover, 'the rights and reputation of others' in Article 10(2) make no reference to religious people. Hence, if Article 9 provides for protection from gratuitously offensive expression, that right must apply to all cultural groups, including followers of non-religious philosophies and politics.

The right to respect for religious feelings has become a key factor in blasphemy cases, a 'right' that ever since Otto-Preminger has been upheld by Strasbourg. Might this understanding be rooted in history? Originally the justification for penalising religious offences was the need to uphold religious orthodoxy. ${ }^{67}$ Blasphemy was originally a crime against God, not against other individuals. This applies to all the Abrahamic religions. ${ }^{68}$

In Christian societies, the understanding of the term blasphemy has changed over time and blasphemy laws have gradually been given new justifications. For example, the Chief Justice in the 1676, UK Taylor's case held that defamation of Jesus was 'not only an offence to God and to religion, but a

\footnotetext{
63 Otto-Preminger-Institut v Austria (n 2),

64 Ibid para 47.

65 Ibid joint dissenting opinion of Judges Palm, Pekkanen and Makarczyk, para 6.

66 Ibid.

$67 \quad$ Leigh (n 10) 58.

68 See eg, T McKenna, 'Treason against God - Some Aspects of the Law relating to Blasphemy' (2001) 5 Southern Cross University Law Review 27.
} 
crime against the laws, state and Government'.69 This understanding was further argued for on the grounds of Christianity's being a 'parcel of the Laws of England'. ${ }^{70}$ Similarly, Greg Taylor has pointed out that the underlying reason for the blasphemy ban in 18th century Austria was both a fear that the state would be punished by the supernatural unless it enforced adequate respect for God, and the idea of religion as a means to enforce law. ${ }^{71}$ In 19th century England blasphemy law was interpreted as a measure to protect the feelings of the members of the Church of England and those who shared the same fundamental beliefs. ${ }^{72}$ Protection of feelings was thus not historically considered a personal right, the goal was to preserve the social structure. The Select Committee on Religious Offences in England and Wales elaborates:

Faith was seen to be the root of society's political and moral behaviour. Therefore, to challenge that faith or to offend against it was to seriously threaten the very fabric of political and moral society and had to be punished severely. ${ }^{73}$

Similarly, in Islam, religious insults have through the ages been perceived as attacks on the deities, rather than violations of personal rights. As in Christianity, blasphemy can also be interpreted as a threat to the civilisation in Muslim culture. In Carl W. Ernst's words:

Blasphemy can also be seen as the equivalent of heresy (zandaqah), a pre-Islamic Persian term used in reference to the revolutionary teachings of Mani and Mazdak; in this sense, it can mean any public expression of teachings deemed dangerous to the state. ${ }^{74}$

Even today the crime against Allah seems to be the rationale for blasphemy law in Muslim majority states. At the same time, religious offences are perceived as

$69 \quad$ R Sandberg and N Doe, 'The Strange Death of Blasphemy' (2008) 71 Modern Law Review 971, 972 .

$70 \quad$ Ibid.

71 G Taylor, 'Austria's Law against Defamation of Religion: A Case Study' (2015) 30(1) Journal of Law and Religion 80, 82.

$72 \quad$ Sandberg and Doe (n 69) 973 .

73 Select Committee on Religious Offences in England and Wales, 'Religious Offences in England and Wales: First Report (Session 2002-2003)' (2003) HL Paper 95, Appendix 3: Blasphemy, para 2.

74 CW Ernst, 'Blasphemy: Islamic Concept' (1987): <https://www.encyclopedia.com/ environment/encyclopedias-almanacs-transcripts-and-maps/blasphemy-islamicconcept>. 
highly political - aggressions against the Muslim world and often as an indication of racism. This understanding manifests eg, when Muslim protests against religious insults are aimed at cultural and political institutions. However, the notion of blasphemy as a personal attack seems common in modern Europe, also among Muslims. For example, Simon Mercieca, a Muslim commentator living in Malta, in arguing for blasphemy laws compares blasphemy to revenge porn:

Revenge porn is all about ruining a person's life. Making fun of religion or individuals is no different. Like revenge porn, blasphemy laws were introduced to prevent such humiliation ... By abolishing Blasphemy Laws, society would be doing a disservice to free speech, as it would be accommodating the views of extremists. ${ }^{75}$

It must be noted that, although the majority of European Muslims find blasphemy insulting, their views on blasphemy laws differ widely. Quoting Tariq Ramadan (a Swiss Muslim) responding to the Danish Cartoons:

What we need now on both sides is an understanding that this is not a legal issue, or an issue of rights. Free speech is a right in Europe and legally protected. No one should contest this. At the same time, there should be an understanding that the complexion of European society has changed with immigrants from diverse cultures. Because of that, there should be sensitivity to Muslims and others living in Europe. ${ }^{76}$

Regardless of modern ideas of blasphemy as an infringement of a personal right, when it comes to blasphemy cases the ECtHR seems concerned with public order, rather than individual rights. In Otto-Preminger, the ECtHR accepted Austria's reasoning that since the film was liable to insult the overwhelming majority of Austrians, the seizure was justified. ${ }^{77}$ Conceivably the historical trend of protecting the Christian majority influenced the Court, but if so, the Judges went astray. Certainly, the ECHR's provisions are grounded on prevalent

75 S Mercieca, 'In Defence of Our Blasphemy Laws' The Independent, 16 January 2015: <https://www.independent.com.mt/articles/2015-01-16/blogs-opinions/Indefence-of-our-blasphemy-laws-6736128876>.

76 T Ramadan, 'Free Speech and Civic Responsibility' New York Times, 5 February 2oo6: <https://www.nytimes.com/2006/o2/05/opinion/free-speech-and-civic-responsibility. html>. 
values and created in order to protect certain moral principles, subscribed to by the majority. Even so, the very purpose of the Convention is to protect the individual from cruelty by the state, non-state actors and the community, not the other way around. When the Convention was drafted, protection from religious insults had never been considered a personal right - at least not in Europe or in other communities where Abrahamic religions were prevalent. The right not to be offended in one's religious feelings is a modern idea, not stemming from religious doctrines. Instead, this new right is the result of the ECtHR giving into some member states' aims to bypass freedom of expression in favour of religious sensitivities.

\subsection{A Vital Element or a Precious Asset?}

When Article 9 was drafted, the first proposal recommended that it should include 'freedom of religious practice and teaching .... ${ }^{78}$ Apparently there were two reasons why this was amended to cover 'thought, conscience and religion'. First, the drafters wanted to emphasise the significance of religious convictions, not just religious practice. Secondly, it was considered important to protect more convictions than religious beliefs, including atheism. ${ }^{79}$ The aim of protecting a wide range of life philosophies is also the reason why the concept 'religion' has never been defined by Strasbourg. ${ }^{80}$

Despite the pluralistic perspective behind Article 9, the ECtHR seems to rank belief systems hierarchically. In Kokkinakis $v$ Greece, the Court explained that the freedom enshrined in Article 9 is;

... one of the most vital elements that go to make up the identity of believers and their conception of life, but it is also a precious asset for atheists, agnostics, sceptics and the unconcerned. ${ }^{81}$

The Court has never explained why it draws a distinction between believers and secularists. Nor does it explain how a freedom that is 'precious' for atheists, becomes 'a vital element of the identity' for believers. ${ }^{82}$ Where is

78 C Evans, Freedom of Religion under the European Convention on Human Rights (Oxford University Press 2001) 39 .

79 Ibid.

8o $\quad$ F Tulkens, 'Freedom of Religion under European Convention on Human Rights: A Precious Asset' (2014) 3 Brigham Young University Law Review 509, 512.

$81 \quad$ Kokkinakis $\left(\mathrm{n}_{3}\right)$ para 31.

82 Ibid. 
the evidence for the assumption that religious beliefs differ from others? The Venice Commission refers to Nikos Alivizatos, ${ }^{83}$ who claims that:

Religious beliefs are much stronger compared to other beliefs, equally significant, but ones that do not concern equally intimate choices. Each person's relation with the metaphysical is usually so complex and special that a relevant offence of similar emotions might well cause a disproportionately severe shock - so severe that it would be natural, not just for the victim, but further for every sensitive person, not to tolerate such an offence. ${ }^{84}$

Alivizatos is a specialist in Greek constitutional law. Nothing suggests that he has done any research on the strength and intimacy of beliefs, and he does not refer to any sources to back up his statement.

Undoubtedly, some religious people feel deeply hurt when their deities or holy scriptures are denigrated. But is there any evidence that they are more vulnerable than others? What about communities that treat their political leaders as deities? Is there any evidence that the devout communist is not devastated by gratuitously offensive statements about Stalin? Might a nationalist not feel just as offended, seeing his flag burnt in a political demonstration, as a Christian witnessing someone spitting on the crucifix? In 2015, 17 people were killed in Paris in revenge for offensive cartoons aimed at Islam. The cartoons were published by the satiric magazine Charlie Hebdo. All over the world, people declared their solidarity under the slogan, 'Je Suis Charlie.. ${ }^{85}$ Sejal Parmar points out that in the wake of the attack, political leaders' support for freedom of speech 'stood as markers of their identity. ${ }^{\prime 6} \mathrm{~A}$ writer describes his reaction:

The instant I heard about the attack on the offices of Charlie Hebdo last week and saw the hashtag 'Je Suis Charlie' - I had no hesitation in posting the slogan as my Facebook cover photo. It was an angry and emotional

83 'Report on the Relationship between Freedom of Expression and Freedom of Religion ...' (n 19) para 48.

84 N Alivizatos, 'Art and Religious Beliefs: The Limits of Liberalism' in Blasphemy, Insult and Hatred: Finding Answers in a Democratic Society Science and Technique of Democracy (Council of Europe Publishing 2010) 47, 73.

85 See eg, N Cox, “The Freedom to Publish "Irreligious" Cartoons' (2016) 16 Human Rights Law Review 195 .

86 S Parmar, 'Freedom of Expression Narratives after the Charlie Hebdo Attacks' (2018) 18(2) Human Rights Law Review 267, 270. 
reaction. I'm a writer - I deal in ideas, words, satire - the attack felt personal. ${ }^{87}$

Might freedom of expression be 'a vital element of identity' for the great number of people who either rallied under the slogan, 'Je Suis Charlie', or posted it as their profile picture on social media?

The Convention drafters' decision to protect secular belief systems under the same provisions as religions seems fair. But the ECtHR's decision to widen the scope of Article 9 to cover a right to respect for feelings can lead to a major dilemma. Even more so since it has not been demonstrated that religious people are emotionally different from followers of political ideology.

\subsection{Whose Feelings?}

Even if we assume that religious beliefs are more significant than any other 'fundamental facet of an individual's identity', another problem that must be addressed is which belief systems qualify as religions. There exists no definition of 'religion' under Strasbourg's' jurisprudence. ${ }^{88}$ Among the life philosophies protected under Article 9 are Scientology ${ }^{89}$ and Veganism. ${ }^{90}$ It remains unclear if these beliefs are protected to the same extent as traditional religions. Some European states recognise the Church of Scientology as a religious entity. Does that mean that the religious feelings of the members are protected under Article 9 to the same extent as those of Christians and Muslims, only in those states that have granted Scientology the status of a religion? The formal status of a belief system cannot determine whether or not the faith qualifies as a vital element of the followers' identity. ${ }^{91}$

\subsubsection{Are all Belief Systems protected?}

Limiting the freedom of speech on grounds of the unique vulnerability of religious people is a slippery slope. Both because the particularity of religious feelings is unfounded and also because there exists no clear, universal distinction between religions and other belief systems. This could get even more complicated. The Pastafarian movement is obviously not a belief system in traditional

87 M Jameson, 'No, Really, Je Suis un Proper Charlie' Ninja Marmoset, 14 January 2015: $<$ https://ninjamarmoset.com/2015/o1/14/je-suis-un-proper-charlie/>.

88 ECtHR 'Guide on Article 9 of the European Convention on Human Rights' (updated 31 August 2020): <https://www.echr.coe.int/Documents/Guide_Art_9_ENG.pdf>.

$89 \quad X$ and Church of Scientology $v$ Sweden $7805 / 77$ (ECtHR, dec, 5 May1979).

9o Wv the United Kingdom 18187/91 (ECtHR, dec, 10 February1993).

$91 \quad$ On the difficulties of defining religion, see eg, R Barker, 'Scientology, the Test Case Religion' (2015) 40 Alternative Law Journal 275. 
understanding. On the contrary, it is founded as a mockery of religious systems. Yet, in recent years the movement has been organising itself in a way similar to religious entities and has developed its own ceremonies. In New Zealand, although the Church of the Flying Spaghetti Monster does not yet have the formal status of a religion, it has been granted permission to perform legal marriages ${ }^{92}$ and the question arises whether this might be a steppingstone for Pastafarians towards being recognised as a religion in some parts of the world.

As it has been established that a belief must 'attain a certain level of cogency, seriousness, cohesion and importance' to be safeguarded under Article 9 of the $\mathrm{ECHR},{ }^{93}$ it is unlikely that Pastafarians or similar groups will be granted a special right to have their religious feelings protected under the jurisprudence of the ECtHR. It must, however, be considered that since the Convention was drafted, the notion of protected religions and beliefs has expanded. For example, a list of belief systems recognised under Article 9 includes Neo-Paganism (Ásatrú) currently operating in Iceland. Even if the Ásatrú draws upon an ancient belief system and culture, it ranks as 'new or relatively new religions' according to the ECtHR Guide on Article 9 of the Convention. Whether the members' feelings are protected to the same extent as of those who belong to 'the 'major' or 'ancient' world religion' has not been tried. ${ }^{94}$ Is there any reason to believe that the Court would not take Ásatrú as seriously as the Abrahamic religions? Here is one example where a problem might arise.

The Icelandic Ásatrú constitution requires everyone to remove the dragonheads from their ship's prow when land is in sight, so as not to scare the spirits of the land. ${ }^{95}$ Would it count as gratuitously offensive to ridicule the members by sailing a dragon-headed boat into the creek near their temple?

It was scholarly interest in the Viking heritage, not faith in the pagan gods, that led to the foundation of the Ásatrú association in $1972^{96}$ and as stated in the Ásatrú code of conduct: 'Members of Ásatrú practise their belief in any way that suits them, as long as it does not violate the law of the land ${ }^{97} \mathrm{I}$ assert that even if some of the members might see the dragonhead scenario as a provocation to their association or even their ideology, they do not truly believe that

K Gilsinan, 'The Church of the Flying Spaghetti Monster' (2016) 318(4) The Atlantic: <http:// link.galegroup.com/apps/doc/A469315183/AONE?u=ustrath\&sid=AONE\&xid=65oc4b79>. 'Guide on Article 9 ...' (n 88) para 16. Ibid para 17. Ásatrú - Inntak hins heiðna síðar, 'Allsherjarlög': <https://web.archive.org/ web/20141018022037/https://www.nat.is/trufelog/asatruarfelagid_htm> para 1.

96 See eg, M Strmiska 'Ásatrú in Iceland: The Rebirth of Nordic Paganism?' (October 200o) 4(1) Nova Religio: The Journal of Alternative and Emergent Religions 106, 113. Ásatrú (n 95) 'Siðapáttur' para 7.
} 
the spirits of the land would feel intimidated, and would not be hurt in their religious feelings. Yet, despite doctrines that seem peculiar in our days, the Ásatrú association is certainly no joke. The leaders take their role as protectors of history, lore and literature seriously and this is a registered religious organisation, entitled to its share of religious tax and the right to conduct funerals and legally binding wedding ceremonies. It is, however, obvious that the association's aim is to preserve cultural heritage and has little to do with faith in the sense of religions of orthodoxy. The dragonhead scenario is unlikely to happen, and obviously it is not an analogy with Sabaditsch-Wolff's comments on Prophet Muhammad's alleged paedophilia, but the example shows what kinds of predicaments may arise from the right not to be offended.

Strasbourg has not ruled on a case where freedom of expression was balanced against the 'religious feelings' of secularists but might that day come? In Wingrove, the Court relied less on Article 9 than it had done in Otto-Preminger. Instead, the restrictions of Article $10(2)$ were read as an obligation to: 'avoid as far as possible an expression that is, in regard to objects of veneration, gratuitously offensive to others and profanatory'. ${ }^{98}$ Judge Pettiti, in a concurring opinion, commented that this restriction should also apply to philosophical convictions, making no distinction between 'religious or secular ideals'. ${ }^{99}$ Leigh observes that according to this broadening approach to the right not to be offended, the premise for state intervention would be even vaguer in the case of offences to other ideology and icons than it is for blasphemy. ${ }^{100}$ Admittedly the boundaries between philosophical convictions and politics are far from clear and some philosophical convictions protected under Article 9 have strong links to controversial political movements, eg the Pro-Life movement and PETA.

\subsubsection{The Social Value Test}

The right to hold an opinion is safeguarded under both Articles 9 and 10 of the ECHR. According to the UN Human Rights Committee, under Article 19 of the ICCPR:

All forms of opinion are protected, including opinions of a political, scientific, historic, moral or religious nature. It is incompatible with paragraph 1 to criminalise the holding of an opinion. ${ }^{101}$

\footnotetext{
$98 \quad$ Otto-Preminger-Institut v Austria (n 2 ) para 52.

99 Wingrove (n 41) dissenting opinion of Judge Pettiti.

100 Leigh (n 10) 6 o.

101 'General comment No. 34 ...' (n 15) para 9.
} 
The same applies to the ECHR. Although freedom of expression is subject to limitations, the right to hold an opinion is not applicable to the limitations and restrictions of Article 10(2). ${ }^{102}$ Therefore, the Convention guarantees the right to despise religions without state interference. However, expressing that contempt may be restricted. According to the judgment in Otto-Preminger, believers:

... cannot reasonably expect to be exempt from all criticism. They must tolerate and accept the denial by others of their religious beliefs and even the propagation by others of doctrines hostile to their faith. ${ }^{103}$

Interestingly, in the same case, the Court noted that speech that violates the rights of others, consequently, cannot be of any value for a democratic society. In the Judges' own words:

... expressions that are gratuitously offensive to others and thus an infringement of their rights, and which therefore do not contribute to any form of public debate capable of furthering progress in human affairs ${ }^{104}$

Where does that leave parody and satire? Satire is gratuitously offensive; a polite satire is a paradox. As it usually carries some political message, satire should be protected on grounds of democratic necessity. But if gratuitously offensive expression cannot contribute to any form of public debate, then prohibiting satire is logical. This is particularly interesting considering the development of the term 'blasphemy' in Europe. In the first days of Christianity in England, denying the truth of Christianity constituted blasphemy. Gradually ' $[t]$ he essence of the offence became a supposed tendency to shake the fabric of society generally.'105 The very purpose of satire is to shake general ideas, norms and values. The idea is that questioning everything that is taken for granted does contribute to a democratic debate.

Leigh suggests that the presupposition that only socially valuable discourse deserves protection, poses a threat for religious views to be considered un-progressive, hence of no value. ${ }^{106}$ This perspective is worth attention. The

\footnotetext{
102 D Bychawska-Siniarska, Protecting the Right to Freedom of Expression under the European Convention on Human Rights: A Handbook for Legal Practitioners (Council of Europe 2017) 13 .

103 Otto-Preminger-Institutv Austria (n 2) para 49.

104 Ibid para 49.

105 P Kearns 'The Ineluctable Decline of Obscene Libel: Exculpation and Abolition' (2007) Criminal Law Review 667, 672.

$106 \quad$ Leigh (n 10) 71.
} 
opinion that homosexual relationships are an 'abomination' is a religious doctrine, widely unquestioned and implemented within the Abrahamic religions through the ages. Homosexuality has been, and still is, condemned on grounds of various biblical passages, ${ }^{107}$ and often subject to capital punishment. Even today, homosexual acts are punishable by death in various states where Islam is the prevailing religion. Although, fortunately, most modern Jews and Christians would not consider homosexuality deserving of the death penalty, it is a wellknown fact that to this day homosexuals face discrimination and persecution, justified by the biblical doctrine of homosexuality (or sodomy) as a grave sin.

Citing bible verses on homosexuality can certainly be a means of inciting hatred but the purpose may also be the Evangelist's sincere concern for the soul of the sinner. The gay community, however, may find the preacher's aim of showing them the way to salvation extremely offensive and in any case these verses can hardly count as a contribution to progress in human affairs. The ECtHR has acknowledged sexual orientations as 'a fundamental facet of an individual's identity'.108 Religious feelings are granted protection on precisely those grounds. If the Court is consistent in its own logic, the feelings of the marginalised LGB T community must deserve protection, even if no incitement is involved. Would the ECtHR uphold states' right to criminalise citing the Bible or Islamic Hadiths on homosexuality? If only a 'debate capable of furthering progress in human affairs' deserves protection, the answer must be yes.

It is concluded that the ECtHR methodology does not provide a clear guidance on whose feelings are protected under the Convention. If Article 9 protects not only the right to religious beliefs and practices, but also the right not to be hurt in one's religious feelings, then it must also enshrine a right not to be offended by other peoples' views on matters of political, scientific, historic or a moral nature. If this holds true, then political parties must also deserve protection against gratuitously offensive expression. The same applies to various minorities, including groups that have been targeted by religious institutions. If this is not the case, then the social value test does not hold up to scrutiny.

This section argues that by defining religious peace not in terms of absence of violence, but in terms of insults to religious feelings, the ECtHR has taken a perilous path. It is argued that 'a pressing social need' to protect groups from

\footnotetext{
107 Genesis 9:20-27, Genesis 19:1-11, Leviticus 18:22, 20:13, Corinthians 6:9-10; Timothy 1:10 and Romans 1:26-27.

108 ÍK $v$ Switzerland 21417/17 (ECtHR, dec, 19 December 2017) para 24.
} 
being offended has not been demonstrated and that Strasbourg's approach to peaceful coexistence has opened a gateway to the protection of political convictions at the expense of religious freedom. The relations between the two major risk factors to religious peace, 'justified indignation' and 'incitement to hatred', are explored. It is suggested that by protecting religious feelings, the ECtHR has blurred the lines between harm to religious feelings and incitement to hatred, to the extent of jeopardising freedom of expression.

\subsection{The Relevance of the Majority}

The ECtHR refers to 'religious peace' in most, if not all, blasphemy cases. Seemingly, religious peace is an even broader concept than the elusive term 'public order' and may be considered 'disturbed' as soon as members of a religious groups have a legitimate reason to feel angry. The tone was set in Otto-Preminger, as the ECtHR agreed that since the overwhelming majority of the population was Roman Catholics, religious peace was jeopardised. ${ }^{109}$ This conclusion rested on the state's claim that the film was likely to cause 'justified indignation'110 and that there had been a pressing social need to 'protect public order against the film. ${ }^{111}$.

In Murphyv Ireland, it was disputed whether a ban on advertising religious events constituted a breach of Article 10.112 Although it was not a blasphemy case, the ruling reflects the significance of a high number of offended civilians. The state argued that 'religion had been a divisive issue in Northern Ireland' and since the vast majority was religious and especially since one church was dominant, advertisements from another church might be interpreted as proselytism. ${ }^{113}$ The ECtHR agreed that the state should conform to the believers' religious sensitivities.

In ÍA $v$ Turkey, the relevance of majority is unclear. The Court noted that neither the majority nor minorities could expect to be exempted from criticism, ${ }^{114}$ but the conclusion rested on the grounds that the disputed book included abusive attacks on Muhammad.

The ECtHR has been criticised for accepting discrimination against religious minorities by referring to the majority in blasphemy cases. Thus, Leigh has argued that in Otto-Preminger, the majority's religious feelings were at stake

\footnotetext{
109 Otto-Preminger-Institut v Austria (n 2) para 56.

$110 \quad$ Ibid para 48.

$111 \quad$ Ibid para 52.

112 Murphyv Ireland 44179/98 (ECtHR, 10 July 2003).

$113 \quad$ Ibid para 73 .

114 ÍA v Turkey (n 47) para 28.
} 
and seemingly on those grounds the state was granted a wide margin to assess the need to protect religious peace. ${ }^{115}$ Similarly, O'Reilly claims that the Court has protected religious feelings of the majority 'to a degree that undoubtedly discriminates against minorities. ${ }^{116}$ Strasbourg could certainly be clearer on the relevance of the majority in blasphemy cases. The rights enshrined in the Convention are individual rights. Protecting groups must therefore require a justification under Article 14 (prohibition of discrimination) and would normally apply to minorities. Since the majority is mentioned it must be relevant, but that relevance remains a mystery.

It seems to me that the Court made a critical mistake in Otto-Preminger, not by referring to the majority, but by accepting Austria's definition of religious peace. A threat of violence would have justified the seizure of the film. Not on grounds of religious rights but on the grounds that the authorities cannot be expected to manage an uproar supported by more than 8 o per cent of the population. Article 10(2) provides for restrictions on grounds of 'public safety' and 'for the prevention of disorder or crime'. It seems implausible that an offensive film would drive Austrian Catholics to burn cars and kill atheists and no such claim was made by the Austrian state. Public order was briefly mentioned without any explanation. However, instead of dismissing Austria's claim that religious peace was at stake, the ECtHR seconded the state's assertions, first of a right to respect for religious feelings, secondly that 'justified indignation' leads to disturbance of religious peace.

As protection of religious feelings has been granted human rights status, the number of possibly offended believers should not matter, and the ruling in ES confirms that the right not to be offended does not just apply to the majority. O'Reilly asserts that in the rare instances when European authorities curb offensive expression aimed at minorities, they are usually not motivated by concern for the victims' feelings but by a perceived threat to public order. ${ }^{117}$ It is hard to say if Strasbourg's ruling in $E S$ reveals the Court's will to prevent discrimination, as no reference was made to Article 14 or minorities. What is clear is that the Court acknowledged that religious peace was at stake. Whatever that means.

As Article 9 covers not only freedom of religion, but also other life philosophies, it is presumed that 'religious peace' enshrines 'peaceful co-existence of all religions and not those belonging to a religious group by ensuring mutual

\footnotetext{
$115 \quad$ Leigh (n 10) 59 .

116 O'Reilly (n 12$) 252$.

117 Ibid 254.
} 
tolerance.'118 Theoretically this broad understanding of religious peace is apt to limit discrimination and provide greater protection for minorities. As argued in the next section the reality may be different.

\subsection{Religious Minorities and Secular Feelings}

Muslims in the Western world frequently experience hostility based on their religious preferences. The European Commission has expressed concerns over increased negativity towards Muslims in Europe in recent years, ${ }^{119}$ and in the US, hate crimes against Muslims have been on the rise since 2015. It has been argued that Islamophobia has become mainstream, at least in the US and France. ${ }^{120}$ The rise of nationalist parties in the Nordic countries may also indicate mainstreaming of Islamophobia. European courts have been criticised for bias in the field of freedom of expression and for applying incitement law selectively. ${ }^{121}$ Legislation aimed at Muslim culture has been upheld by the ECtHR, at least in 'headscarves' cases.

However, in the context of the freedom to criticise religion, it cannot be ignored that interpretations of Islam acknowledged and enforced by states like Saudi Arabia, Afghanistan, Pakistan, etc. contradict international human rights standards. This has been confirmed by the ECtHR. In the case of Refah Partisiv Turkey, an Islamic political party that promoted armed jihad was dissolved on the grounds that it posed a threat to secularism and democracy. ${ }^{122}$ The Court did not find a violation of Article 11 and saw no reason to examine Articles 9 and 10 separately. ${ }^{123}$ Declaring Sharia incompatible with the Convention, the ECtHR noted that the party's 'offending statements, which contain explicit references to the introduction of sharia, are difficult to reconcile with the fundamental principles of democracy, as conceived in the Convention taken as a whole.' 124

The Refah leaders had promoted wearing Islamic headscarves as a means of advocating Sharia. In Leyla Şahin $v$ Turkey, the applicant wanted to wear

See eg, Leyla Şahin v Turkey [GC] 44774/98 (ECtHR, 10 November 2005) paras 107-108.

European Commission, 'Combating Anti-Muslim Hatred': <https:/ec.europa. eu/info/policies/justice-and-fundamental-rights/combatting-discrimination/ racism-and-xenophobia/combating-anti-muslim-hatred_en>.

A Mondon and A Winter, 'Articulations of Islamophobia: From the Extreme to the Mainstream?' (2017) 40(13) Ethnic and Racial Studies 2151.

P Noorlander, 'In Fear of Cartoons' (2015) 2 European Human Rights Law Review 115.

Refah Partisi (the Welfare Party) and Others $v$ Turkey [GC] 41340/98, 41342/98, 41343/98, 41344/98 (ECtHR, 13 February 2003).

Ibid para 137 .

Ibid para 123 [emphasis added]. 
a headscarf at her University. Turkey's Constitutional court held that as the majority of students were Muslims, presenting headscarves as a religious obligation 'would result in discrimination between practising Muslims, non-practising Muslims and non-believers.' ${ }^{25}$ The ECtHR, referring to Refah, acknowledged that in Turkey, Islamic headscarves were perceived as symbols of political views that contradicted democratic values. ${ }^{26}$ The Court recognised the state's right 'to secure civil peace and true religious pluralism,', 27 and its 'aim of ensuring peaceful coexistence between students of various faiths and thus protecting public order and the beliefs of others'.128 Leyla Şahin had not been accused of promoting jihad or Sharia law, but since Refah had promoted headscarves, it could have a proselytising effect.

In $S A S v$ France, the full-face veil ban was based on a report drafted by a parliamentary commission. ${ }^{129}$ The commission reported that the veil was rooted in fanatical movements and represented a denial of the principles of liberty, equality and fraternity. Consequently, French courts held that wearing a veil was 'incompatible with the fundamental requirements of 'living together' in French society'.130

The ECtHR did not accept the state's claim that the veil ban was necessary for public safety. However, the Court conceded that the principle of living together' justified a ban on full-face veiling, as 'the face plays an important role in social interaction.' ${ }^{\prime 31}$ Two of the Judges dissented from the majority's conclusion on accepting a blanket ban on a full-face veil, reasoning that such a ban, 'sacrifices concrete individual rights guaranteed by the Convention to abstract principles'. Furthermore, they found it doubtful that the ban could serve any legitimate aim and found 'such a far-reaching prohibition, touching upon the right to one's own cultural and religious identity, ... not necessary in a democratic society.'132

Despite the Court's dismissal of France's reasoning of public safety, and although the Court seemed reluctant, the Grand Chamber did accept the claim that the veil violated the rights of others (the right to 'living together') and

\footnotetext{
125 Leyla Şahin (n 118) para 39.

126 Ibid para 93.

127 Ibid para 110.

128 Ibid para 111 [emphasis added].

129 SAS $v$ France $\left(\mathrm{n}_{3}\right)$ paras $15^{-17}$.

130 The assumption that the principle of 'living together' requires being able to look others in the eye has been challenged. See, Y Hakeem, 'S.A.S. v. France: Supporting "Living Together" or Forced Assimilation?' (2014) 3(2) International Human Rights Law Review 277.

$131 \quad S A S v$ France (n 3) para 122.

132 Ibid joint partly dissenting opinion of Judges Nussberger and Jäderblom.
} 
- referring to France's margin of appreciation - concluded that the restriction served a legitimate aim and was necessary in a democratic society.

Strasbourg's holdings in the Muslim scarf cases lead to interesting conclusions:

- Islamic headscarves have in some states become political symbols, offending to democratic values.

- Peacefully manifesting one's religion, by wearing such symbols, may infringe the rights of others and jeopardise pluralism, tolerance and peaceful co-existence.

- A pressing social need for protecting 'civil peace' and the peaceful coexistence of people with different beliefs, may in some cases justify restrictions on religious freedom, to the extent of deeming garments, worn by peaceful Muslim women, all over the world, too offensive to be tolerated in the public square.

This conclusion would have been expected had the applicant claimed a right to wear a Ku Klux Klan hood - unquestionably a symbol of racism and persecution. The full-face veil may be rooted in fundamentalism and in some cases used as political symbol, but to most Muslim women who claim the right to wear a headscarf it is a symbol of modesty. It must be considered that in Muslim culture, modesty is perhaps the most important of female virtues and an essential part of a woman's identity and her commitment to Allah. ${ }^{133}$ The message that the average Muslim woman is conveying by wearing this piece of cloth is 'here goes a virtuous lady', not 'here goes an oppressed woman' or 'here goes a terrorist'. It seems unreasonable to treat everyday clothing of millions of women as a symbol of extremism, thereby justifying restrictions of religious practises.

In none of these cases was 'religious peace' mentioned, but in Leyla Şahin, the need to preserve 'civil peace' was acknowledged. ${ }^{134}$ Apparently, the ECtHR has adopted Judge Pettiti's opinion that secular ideals should be protected from offensive expression. ${ }^{135}$ Despite no reference to a right not to be offended in one's secular feelings, that kind of a right seems to be the underlying reason. The mere presence of a symbol perceived as offensive to democratic values is a threat to 'peaceful coexistence' and is treated, by the ECtHR, as somewhat akin to blasphemy. Denigrating Jesus poses a threat to religious peace, expressing

133 On Muslim women's view on the hijab and the virtue of modesty, see eg, A Siraj 'Meanings of Modesty and the Hijab amongst Muslim Women in Glasgow, Scotland' (2011) (18)6 Gender, Place \& Culture: A Journal of Feminist Geography 716.

134 Leyla Şahin v Turkey (n 118) para 110.

135 See, Section 3.4.1. 
contempt for democracy and jeopardises civil peace. However, there is a significant difference: in none of the cases where Muslims' religious freedom has been restricted in the name of peaceful co-existence, has 'justified indignation' been mentioned.

\subsection{Justified Indignation}

The Western world's increasing intolerance of Islam may have more complicated reasons than sheer prejudice. In Neville Cox's opinion, the widespread solidarity with Charlie Hebdo in the aftermath of the 2015 attack can largely be explained by Islamophobia. Cox points out that there is 'no equivalent global call for an unabridged freedom to publish cartoons mocking severely physically disabled children or victims of the holocaust.' ${ }^{136}$ That holds true, but it cannot be stated that massacre in the name of Jahve or Zion would not ignite a campaign for defending the right to insult Jews or ridicule the Holocaust. Furthermore, the Charlie Hebdo affair is not the only incident in Europe in recent decades of violent reactions to blasphemy against Islam.

Besides cases where individual offenders have been persecuted or murdered, the Rushdie affair starting in 1988, the Danish Cartoons in 2005 and the film trailer, 'Innocence of Muslims' in 2012, all provoked assassination attempts and violent riots, resulting in high death toll of people who had nothing to do with the offences. In all cases, Muslim majority countries suffered the most. Importantly, while numerous Muslim leaders and organisations have condemned violence as a reaction to blasphemy, it has also been triggered by Islamic leaders and media. A stunning example: responding to the Satanic Verses, Ayatollah Khomeini declared a 'fatwā', an authoritative, yet not binding, interpretation of the Sharia Law ${ }^{137}$ calling for all Muslims to kill Rushdie. Numerous media outlets placed a joint bounty on the author's head. Rushdie was in hiding and under police protection for ten years. The fatwā was renewed and the bounty raised in 2016. ${ }^{138}$

None of the blasphemy controversies mentioned above has been tried at Strasbourg. The Danish authorities, despite pressure from the Organisation of Islamic Cooperation, refused to prosecute. An application to the ECtHR,

\footnotetext{
$136 \quad \operatorname{Cox}($ n 85) 212.

137 RE Howard-Hassmann, 'The Charlie Hebdo Murders and Freedom of Speech' (2015) Journal of International and Comparative Law 467, 468.

138 'Iranian State Media Has Put a $\$ 600,000$ Bounty on Salman Rushdie's Head', The Independent, 21 February 2016: <https://www.independent.co.uk/news/people/salmanrushdie-iranian-state-media-renew-fatwa-on-satanic-verses-author-with-6ooooobounty-a6887141.html>.
} 
relying on Article 9, was rendered inadmissible since the applicants lacked legally protected interests. Three Charlie Hebdo cartoons were challenged at the domestic level in France in 2007. The court concluded that the cartoons did not overstep the cartoonists' freedom of expression. ${ }^{39}$ According to the decisions in Denmark and France, the cartoons were not 'apt to incite justified indignation'. Manifestly those who filed charges and those who carried out the violence did not agree with that assessment.

Religious or not, civilians experience justified indignation daily. Protests, strikes, activism involving civil disobedience and direct actions are driven by intense displeasure. Usually, governments are not overly concerned with justified indignation unless they face either loss of votes in the next elections or a risk to public order. When the authorities decide to increase health care allowances, it is justified by benefits to society or humanitarian views. It may result in less anger, but the premise is not people's annoyance, at least not in the absence of vandalism and violence. Would any European state silence offensive political expression on the grounds that it might cause justified indignation' resulting in Antifa-riots? No - because taking an offence from other people's opinions does not justify violence.

If the authorities can manage political anger, then why should the wrath of believers result in restrictions on fundamental freedoms? What 'pressing social need' are the states talking about when they restrict free speech or the freedom to manifest one's religion, in the name of peaceful coexistence, and why does the ECtHR acknowledge such reasoning? Might Strasbourg's approach to blasphemy be influenced by the view that religious insults are rooted in hatred?

\subsection{Religious Hatred}

In 2007 PACE recommended that 'blasphemy, as an insult to a religion, should not be deemed a criminal offence. ${ }^{140}$ Member states should only criminalise religious insults that incited hatred, discrimination or violence on grounds of religion and only if the expression was aimed at a person or a particular group of people. ${ }^{141}$ Furthermore, the offence must be intentional and call for violence.'142 It is, nevertheless, noted that religious groups should not have to tolerate 'intentional and gratuitous insults.' ${ }^{143}$ How does this reference to groups' sensitivities comply with the assertion that religious insult should

\footnotetext{
139 On the French and Danish cartoon cases, see eg, Noorlander (n 121).

140 'Recommendation 1805' (n 61) para 4.

141 Ibid para 12.

142 Ibid para 15.

143 Ibid para 5.
} 
not be criminalised? If this is not a paradox, then it seems to imply that when it reaches a certain level of seriousness, a religious insult incites hatred. Incitement to hatred is thus projected by threatening behaviour or expression, whereas harm to religious feelings may be obnoxious - yet not apt to encourage discrimination or violence.

According to Article 20 of the ICCPR, 'any advocacy of national, racial or religious hatred that constitutes incitement to discrimination, hostility or violence shall be prohibited by law.' The ECHR contains no provision on hatred, but discrimination is prohibited under Article 14 and Article 17 states that nothing in the Convention may be interpreted as 'any right to engage in any activity or perform any act aimed at the destruction [of Convention rights].' These provisions provide a ground for criminalising incitement to violence and discrimination against minorities. The UN Human Rights Council also draws a direct connection between hate crimes and religious insults: 'Defamation of religion is a serious affront to human dignity leading to a restriction on the freedom of adherents and incitement to religious violence.' 144 This implies that hostile criticism of religion may incite supporters of those views to carry out violence against the followers of that religion or sect. ${ }^{145}$

No international definition of hate speech exists, but definitions used by international bodies since the Holocaust have presumed that to qualify as 'hate speech' the expression must be liable to incite hatred. ${ }^{146}$ In the European Council's 1997 guidelines on hate speech, the following definition is suggested:

"hate speech" shall be understood as covering all forms of expression which spread, incite, promote or justify racial hatred, xenophobia, anti-Semitism or other forms of hatred based on intolerance, including: intolerance expressed by aggressive nationalism and ethnocentrism, discrimination and hostility against minorities, migrants and people of immigrant origin. ${ }^{147}$

The terminology has developed since 1997 and 'hate speech' is now understood as a broader term than 'incitement to hatred'. Whereas hate speech can

\footnotetext{
144 UN Human Rights Council, 'Combating Defamation of Religions: Resolution 13/16' (adopted by the Human Rights Council 15 April 2010) Doc. A/HRC/RES/13/16, 2.

145 Sturges (n 30) 116.

146 J Temperman, Religious Hatred and International Law: The Prohibition of Incitement to Violence or Discrimination (Cambridge University Press 2016) 168.

147 Council of Europe 'Recommendation R (97)20 of the Committee of Ministers to the Member States on Hate Speech' (adopted by CoM 30 October 1997 at the 6o7th meeting of the Ministers' Deputies) Appendix; 'Scope'.
} 
hurt the targets, to qualify as 'incitement' the expression must be likely to influence a third party to harm the target group, and the risk must be imminent. ${ }^{148}$ Moreover, blasphemy is apt to evoke feelings of hurt, insult and anger, whereas the European Commission against Racism and Intolerance describes hate speech as leaving the targets 'feeling afraid, insecure and intimidated.'149 Virtually all states parties to the CoE penalise incitement to hatred, drawing upon the 1997 guidelines' definition, most of them with religious hatred as a subset. 150

According to the ECtHR case law, Article 10 does not protect incitement to discrimination, negative stereotyping or direct insults towards a particular group. In Féret v.Belgium, slogans such as 'Stand up against the Islamification of Belgium', carried out in the context of political elections, were considered apt to incite distrust towards Muslims and encourage their marginalisation. ${ }^{151}$ Other applications concerning hatred against Muslims, expressed in a similar manner, have been found inadmissible. ${ }^{152}$ Soulas and Others $v$ France concerned criminal convictions for incitement communicated in a book about Islam and immigration. As the book was coloured by negative stereotyping of Muslims, claiming that the rise of Islam in Europe marked the beginning of an ethnic civil war, the ECtHR found no violation of Article 10.153

These cases differ significantly from blasphemy cases as here the discourse targets a religious group directly. Whereas blasphemy leads to justified indignation among believers, incitement leads to risk of violence against the target group.

\subsection{The Risk Model}

The UN High Commissioner for Human Rights has recommended that in assessing incitement to hatred, six factors should be tested: a) social or political context; b) the speaker's status and influence; c) the speaker's intent; d) the content, form and style of the discourse; e) the extent of the speech, such as venue and audience; f) the likelihood of inciting direct action against the

\footnotetext{
148 Temperman (n 146) 180.

149 European Commission against Racism and Intolerance (ECRI), 'Recommendation nr. 15 on Combating Hate Speech' (adopted 8 December 2015) (CRI 2016) 15.

150 'Report on the Relationship between Freedom of Expression and Freedom of Religion ...' (n 19) para 43.

$151 \quad$ Féret v Belgium 15615/o7 (ECtHR, 16 July 2009) para 78.

152 Norwood $v$ the United Kingdom 23131/o3 (ECtHR, dec, 16 November 2004); Belkacem $v$ Belgium 34367/14 (ECtHR, dec, 27 June 2017); Le Pen v France 18788/og (ECtHR, dec, 7 May 2010).

153 Soulas and Others $v$ France 15948/03 (ECtHR, dec, 10 July 2008).
} 
targets. ${ }^{154}$ These are almost the same criteria as for balancing freedom of expression against religious feelings. The only relevant difference is incitement. The main difference between religious insults and hate speech is that the latter is aimed at individuals or groups. However, there is no clear line insults aimed at religion can be a means of expressing contempt towards the believers. When the Danish Nationalist Party used a drawing of Muhammad's head on a dog's body in its election campaign in $2007,{ }^{155}$ it conveyed a message on immigration, no less than on Islam.

The lines are blurred. Gratuitously offensive blasphemy merges with hate speech, that may or may not incite hatred. And although the ECtHR has never said it straight out, justified indignation may, or may not, drive believers to violence. Apparently, this is the model for risks to religious peace:

PACE has noted that 'neo-Nazi activists in the public arena are becoming progressively more sophisticated and thus more difficult to identify and counteract.'156 Rudeness is not necessary to incite hostility. Politely, but repeatedly, expressing concerns about abusive culture and undemocratic values may prove more effective in the long run. However, combating hatred by criminalising discourse that can reasonably be interpreted as a political opinion contradicts PACE's requirements for penalising expression about religion and may jeopardise freedom of expression. It is therefore urgent that legislators and courts act with great caution in sanctioning religious insults. As highlighted by the Venice Commission:

It is true that the boundaries between insult to religious feelings (and even blasphemy) and hate speech are easily blurred, so that the dividing line, in an insulting speech, between the expression of ideas and the incitement to hatred is often difficult to identify. This problem however should be solved through an appropriate interpretation of the notion of

154 UN Office of the High Commissioner for Human Rights (онснR), 'Report of the United Nations High Commissioner for Human Rights on the Expert Workshops on the Prohibition of Incitement to National, Racial or Religious Hatred, $A / H R C / 22 / 17 / A d d .4$, 5 October 2012, appendix ("The Rabat Plan of Action on the Prohibition of Advocacy of National, Racial or Religious Hatred that Constitutes Incitement to Discrimination, Hostility or Violence') para 29.

155 'Skal Bruke Muhammed-Tegning i Valgkampen', Dagbladet, 25 October 2007: <https:// www.dagbladet.no/nyheter/skal-bruke-muhammed-tegning-i-valgkampen/66397215>.

156 Parliamentary Assembly of the Council of Europe (PACE), Resolution 2011(2014), 'Counteraction to Manifestations of Neo-Nazism and Right-Wing Extremism' (2014) para 3 . 
incitement to hatred rather than through the sanctioning of insult to religious feelings. ${ }^{157}$

Unfortunately, the ECtHR has not followed this advice. Contrarily, it has upheld protection of religious feelings to the extent that it is almost unpredictable what kind of expression on religion may be restricted. This is conspicuous in Es v Austria. The clear distinction that must be drawn between religious insults and incitement to hatred has thus been blurred.

This section analyses the case $E S v$ Austria. ${ }^{158}$ The ECtHR's reasoning is scrutinised, and the political context of the case explored. It is suggested that the thin line between religious insults and hate speech may have influenced Strasbourg's holdings in this case and that the Court's approach to safeguarding religious peace has reached the point of giving into perceived danger of violent reaction to blasphemy, even when the indignation cannot be justified.

\subsection{The Es Case in a Nutshell}

The applicant, Elisabeth Sabaditsch-Wolff, is a prominent member of the Austrian Freedom Party (FPÖ). In 2008-2009, the party hosted a series of seminars titled, 'Basic Information on Islam', where the applicant, presented as an expert on Islam, gave talks. The seminars were open to the public, promoted by leaflets and introduced on the party's website. ${ }^{159} \mathrm{~A}$ journalist recorded two of these seminars, apparently with the purpose of uncovering religious hatred. She handed the recordings over to the police. ${ }^{160}$ Consequently, Sabaditsch-Wolff was prosecuted for inciting hatred towards Muslims. ${ }^{161}$ The Regional Court dismissed the allegations of incitement, but three of her comments were classified as 'disparaging religious doctrines' ${ }^{162}$ The case was then tried at the Vienna Court of Appeal, ${ }^{163}$ and finally in the Supreme Court. ${ }^{164}$

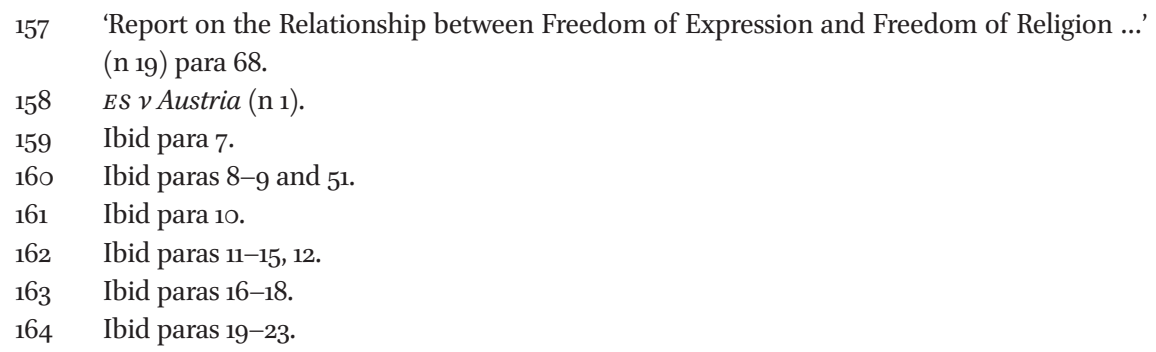


The comments concerned Prophet Muhammad's relationship with his child bride Aisha. The applicant had first stated that Muhammad had been sexually attracted to children, and that since Muslims see him as the perfect human, their belief conflicts with Western values and democracy. Secondly, she argued that all Muslims recognised the Hadiths where the thing with Aisha and child sex is written ...'. In the last comment she referred to an Austrian criminal case where calling the Prophet 'a child molester' was found punishable. Es then asked: 'What do we call it, if it is not paedophilia?'165

Es's defence relied on the reasoning that she had been addressing a political issue: present-day child marriages. ${ }^{166}$ Austrian courts did not accept that argument. At all three judicial levels, ES was found guilty of breaching Article 188 of the Austrian Criminal Code, which criminalises disparaging religious doctrines and other behaviour that is 'likely to arouse justified indignation'.167

In assessing whether the conviction was compatible with Article 10 of the ECHR, the Supreme Court found that her statements, counting as value judgments, lacked factual basis, hence they were not protected under Article 10. Es's intent had not been to contribute to serious debate on Islam or child marriages, but maliciously to defame Prophet Muhammad, thereby hurting the feelings of Muslims. Despite presenting herself as a scholar, Es had not discussed the topic objectively; she had talked in a provocative manner apt to cause justified indignation. The Supreme Court concluded that the state's interference with Es's freedom of expression was justified under Article 10(2) of the ECHR, by the legitimate aim of protecting religious peace and the religious feelings of others. ES was fined 480 euros or to otherwise serve 6o days in prison. 168

Es turned to Strasbourg. The ECtHR held that states have a positive duty under Article 9, of ensuring the peaceful coexistence of all religions. Noting that the applicant's remarks included 'untrue facts' the Court unanimously upheld all of Austria's arguments and concluded that Austrian courts had properly balanced the applicant's freedom of expression with the religious rights of others. ${ }^{169}$ Moreover, the sentence had been proportionate. ${ }^{170}$

Curiously, although Sabaditsch-Wolff was not convicted of incitement, the ECtHR cited an Austrian incitement provision (Article 283 of the Criminal

\footnotetext{
165 Ibid para 13.

166 Ibid para 14-16.

167 Ibid paras 17-22, 21.

168 Ibid paras 21-23.

169 Ibid paras $5{ }^{2-55}$.

$170 \quad$ Ibid para 57.
} 
Code) as 'relevant domestic law', ${ }^{171}$ as well as various international materials on hate speech. ${ }^{172}$ How can a law provision rejected by the domestic courts be relevant? And how can Article 2O(2) of the ICCPR, that provides for prohibition of incitement, be relevant in a case where there was no incitement?

\subsection{The Freedom Party's Links to Nazism}

The FPÖ is a national right-wing party, vehemently opposed to immigration and known for hostility towards Muslims and Jews. When the Party came in second in the parliamentary elections and formed a government in 2000, 14 European states adopted sanctions against Austria, the main reason being the FPÖ's xenophobia. ${ }^{173}$

Sabaditsch-Wolff is not the first Austrian prosecuted for calling Muhammad a paedophile. In 2009, another FPÖ member, Susanne Winter, was convicted under Article 188 for similar wording: 'In today's system, this Muhammad is a child molester.'174 She was also convicted of incitement, having on the same occasion said that 'Islam should be thrown back where it came from, at the other side of the Mediterranean' and suggested that animal brothels might prevent Muslims from raping young girls. ${ }^{175} \mathrm{~A}$ former leader of the party's youth movement, Michael Winter (Susanne's son), has also been convicted of hate speech against Muslims. ${ }^{176}$ Even general members have been convicted of holocaust denial or incitement to hatred against Muslims. ${ }^{177}$

Although the party's leaders claim zero tolerance for the glorification of Hitler and the Third Reich, ${ }^{178}$ it seems implausible that their immigration policy is independent of the fact that the FPÖ is historically rooted in the Nazi

\footnotetext{
$171 \quad$ Ibid para 24.

172 Ibid paras $26-31$.

173 HB Freeman, 'Austria: The 1999 Parliamentary Elections and the European Union Members' Sanctions' (2002) 25(1) Boston College International and Comparative Law Review 109, 110.

174 Wikipedia, 'Susanne Winter': <https://de.wikipedia.org/wiki/Susanne_Winter>.

175 'Susanne Winter Wegen Verhetzung Verurteilt', ORF.at, Steiermark News, 22 January 2oog: $<$ https://stmvi.orf.at/stories/3368o8>.

176 'Urteil Gegen Michael Winter Rechtskräftig', ORF.at, Steiermark News, 1 December 2008: $<$ https://stmvi.orf.at/stories/325924>.

177 See eg, Article 19, 2018 Country Report, 'Austria Responding to Hate Speech' Free World Centre (September 2018): <https://www.article19.org/wp-content/uploads/2018/og/ Austria-Responding-to-Hate-Speech-.pdf $>22$.

178 'Austria's Far-Right Party Hit by yet Another Nazi Scandal', Timesofisrael.com 23 March 2018: <https://www.timesofisrael.com/austrias-far-right-party-hitby-yet-another-nazi-scandal/>.
} 
Party, inspired by Nazi ideology ${ }^{179}$ and has attracted Nazi sympathisers. ${ }^{180}$ Besides numerous convictions, FPÖ members have frequently been criticised for racism and religious hatred, eg for referring to Muslims as cancer and Jews as 'land plague.'181 Although FPÖ leaders deny allegations of racism, their discourse supports the opinion that racism and religious hatred is far from being eradicated amongst them. In January 2018, Herbert Kickl, the Minister of Interior affairs at that time, announced the government's intent to create service centres, that would enable Austrian authorities to keep asylum seekers 'concentrated in one place.' ${ }^{182}$ Whether or not the provocation was intentional, Kickl's use of a Nazi linked terminology sparked an outrage. ${ }^{183}$

In this atmosphere of the Freedom party's hostility towards immigrants and years of its critics' cumulative anger, an effort to get its leaders prosecuted for religious hatred is predictable. However, the speaker's political convictions cannot determine the gravity of the offence. As will be argued, her comments were not without factual basis and should be protected under Article 10, as political criticism.

\subsection{The Factual Basis of the Impugned Statements}

The ECtHR's conclusion that ES did not provide evidence for the prophet's paedophilia seems curious for two reasons. First, applying the value judgment doctrine seems inappropriate in this case. An important question in cases concerning the right to reputation is whether the disputed expression is presented as informative or an opinion. The main difference between a factual statement and value judgment is that a factual statement is provable. ${ }^{184}$ There is much greater leeway for an offensive value judgment. Nevertheless, a value judgement that has no factual basis may overstep the limit of protected speech and the seriousness of the allegation depends on the circumstances of the case. ${ }^{185}$

179 K Engelhart, 'The Return of Hitler: The Troubling Resurgence of His Ideas and Manifesto, “Mein Kampf"' (Maclean's, 21 April 2010): <https://www.macleans.ca/news/world/ th:-return-of-hitler/>.

180 F Hafez and R Heinisch, 'Breaking with Austrian Consociationalism: How the Rise of Rightwing Populism and Party Competition Have Changed Austria's Islam Politics' (2018) 11(3) Politics and Religion 649.

181 See eg, 'Austria Responding to Hate Speech' (n 177) 41.

182 'Kickl Will Asylwerber "Konzentriert" An Einem Ort Halten', ORF.at News, 11 January 2018: $<$ https://orf.at/v2/stories/2422072/>.

183 DStrigl, 'Österreich:WiderEinePolitikRechterNadelstiche',ZeitOnline,15May 2018:<https:// www.zeit.de/kultur/literatur/2018-o5/oesterreich-koehlmeier-winkler-schriftsteller>.

184 Lingens $v$ Austria 9815/82 (ECtHR, 8 July 1986) para 46.

185 Rainey, Wicks and Ovey (n 40) 500. 
According to the ECtHR, Sabaditsch-Wolff's impugned statements were value judgments, but as her allegations of the Prophet being a paedophile had no factual basis, she had exceeded her freedom of speech. Since paedophilia is unacceptable in Austrian society, such allegations were considered an abusive attack on the Prophet and insulting to his followers. ES is not the only case concerning religious insults where the factual basis test has been used. It was applied in the case of Giniewskiv France, where the applicant had been convicted of defaming the Christian community. ${ }^{186} \mathrm{~A}$ 'religious group' consists of individuals, people who are protected from defamation under the law. But on what grounds was the value judgment test applied in $E s$ ? This was not a libel case. The Prophet has been dead for 14 centuries. He is not a legal person and is not protected from defamation or libel.

Secondly, by the words, 'liked to do it with children' and 'child sex', ES was referring to Islamic scriptures, Hadiths, that rank next to the Quran as guidance on Islamic law and include records of historical events. ${ }^{187}$ Aisha's age of marriage is mentioned many times in the Hadiths. Quoting Aisha herself, the writer claims that she married Muhammed at the age six or seven and that the marriage was consummated three years later. ${ }^{188}$ The accuracy of Aisha's age or marriage is disputed among modern Islamic scholars, but most Muslims still rely on these Hadiths. Notwithstanding the accuracy of holy scriptures, Sabaditsch-Wolff was referring to texts that have, through the ages, been interpreted as accurate and true. ${ }^{189}$ The Austrian Court of Appeal actually noted that her statements were 'wrong and offensive, even if Muhammad had married a six-year-old and had intercourse with her when she had been nine.' The truth seems irrelevant here.

In a commentary on the judgment, Stijn Smet uses the word 'dumbfounded' about his reaction to the Court's approach to the truth of the statements in distinguishing between factual statements and value judgments. Quoting Smet:

By going down this road, the Court reduces the case to a single factual question: is having sex with one child 1,400 years ago enough to be labelled a paedophile today? That is an exceedingly narrow view of the case and entirely unhelpful for its resolution. ${ }^{190}$

\section{Giniewsky v France (n 4).}

187 AK Cragg, 'Hadith' in Encyclopedia Britannica (August 2020): <https://www.britannica. com/topic/Hadith>.

188 S Al-Bukhari, 'Wedlock, Marriage (Nikaah)' in Book 62, paras 64-65.

189 HG Koenig and SA Shohaib, Health and Well-Being in Islamic Societies: Background, Research, and Applications (Springer 2014) 30.

190 S Smet, 'ES v Austria: Freedom of Expression Versus Religious Feelings, the Sequel' (Strasbourg Observers, 7 November 2018): <https://strasbourgobservers.com/2018/11/o7/es-v-austria-freedom-of-expression-versus-religious-feelings-the-sequel/>. 
Apart from the absurdity of the term 'untrue facts' (a fact is by definition true), the claim that Es's statements are untrue is at least questionable. The Austrian courts' reasoning for her statements being untrue was that $\mathrm{ES}$ had failed to note that the marriage continued through Aisha's adulthood and that Muhammad's other wives were adults by the time of their marriages. According to the definition acknowledged by the World Health Organisation, 'paedophilia was a primary sexual interest in children who had not yet reached puberty' ${ }^{191}$ Therefore, allegations of paedophilia did not hold up to scrutiny. Moreover, the scriptures did not imply that the Prophet had any sexual relationship with 'children' but Es had nevertheless used the plural. ${ }^{192}$ Frankly, this reasoning is sophistry. Manifestly, the applicant did not provide evidence for the prophet's sexual preferences, but she was obviously condemning sexual behaviour. Most people do not care whether or not child molesters have sexual tendencies towards their adult wives. It is the harm done to their victims that matters.

Judging a 7 th century man by the moral standards of contemporary Europe is extremely unfair and far from representative for academic expertise on Islam. It is, however, not an indisputable fact that Muhammad is a desirable role model. When Es asked what the Prophet's relationship with Aisha should be called if not paedophilia, she was referring to Susan Winter's case, pointing out that in contemporary Europe, Muhammed would be defined a paedophile. 'What do we call it?' When a European democracy restricts the freedom to criticise the glorification of a 7 th century man who, according to the scriptures lived by $7^{\text {th }}$ century morals, that is a legitimate, political question.

\subsection{Child Marriages as a Political Issue}

Europe's extreme nationalist parties claim that people with non-Western backgrounds have morals and lifestyle choices incompatible with Western values, that Muslims are aiming to impose Sharia law on Europe, and that a great number of immigrants will eventually bring Europe back to the middle ages. ${ }^{193}$ These ideas are systematically exploited to fuel Islamophobia and justify strict immigration policies and ruthless treatment of refugees. ${ }^{194}$ Sadly,

\footnotetext{
$191 \quad$ ES $v$ Austria (n 1$)$ para 17.

192 Ibid para 18.

193 M Ekman, 'Online Islamophobia and the Politics of Fear: Manufacturing the Green Scare' (2015) 38(11) Ethnic and Racial Studies 1986.

194 This is evident from articles recommended by and published on these parties' websites. See eg, British National Party, 'Reversing the Islamisation of Britain' (14 February 2020): $<$ https://bnp.org.uk/reversing-the-islamisation-of-britain/>; Alternative für Deutschland: Andreas Kalbitz, 'Islamists Are a Double Danger for Our Society' (no date): <https://www. afd.de/andreas-kalbitz-islamisten-sind-fuer-unsere-gesellschaft-eine-doppelte-gefahr/>;
} 
statements about indefensible third world cultures sometimes contain a grain of truth. According to UNICEF statistics, 21 per cent of girls worldwide are married before the age of 18 and 5 per cent before 15 , the highest rate in the least developed countries. ${ }^{195}$ Child marriages are certainly not limited to Muslim countries and social factors like poverty and deeply rooted misogyny are more relevant causes than religions. ${ }^{196}$ However, Muhammad's status as 'the perfect example' has been used to justify child marriages. In 1986, Ayatollah Khomeini, interpreting the holy scriptures, wrote:

Anyone who has a wife less than nine years of age is not allowed to engage in sexual intercourse, whether she is his permanent or temporary wife. However, other forms of sexual pleasures are permitted, such as touching with lust, hugging, and rubbing penis between the buttocks and thighs; even if she is a nursing baby. ${ }^{197}$

Now, what do we call this conduct described by the Imam? Would calling Khomeini a 'paedophile apologist' be considered a contribution to a public debate or an attack on the religious feelings of those who appreciate his interpretation?

Although not commonplace, child marriages have not been abolished in Iran. As late as 2013 the Office of the High Commissioner for Women's Rights and Gender Section reported that Parliament's legal affairs committee was advocating the legal age of marriage to be pushed back to nine. ${ }^{198}$ Even in Turkey, a member of the ECHR, support for child marriages thrives. In 2016 the Turkish government withdrew a bill that proposed pardoning men of child sex convictions if they had married the victim. In January 2018 a religious

Dansk folkeparty: Kristian Thulesen Dahl, 'Dansk Folkepartis vigtigste opgave: Danmark må aldrig blive islamiseret' (12 February 2019): <https://danskfolkeparti.dk/danskfolkepartis-vigtigste-opgave-danmark-maa-aldrig-blive-islamiseret/>. These are just a few examples; the overwhelming majority of articles on Islam and Muslims on these websites and other nationalist parties reflect these views. UNICEF Data: 'Monitoring the Situation of Children and Women' (March 2018): <https:// data.unicef.org/topic/child-protection/child-marriage >.

196 S Khazaei, K Mansori, Z Khazaei and E Auybi, 'A Look at the Phenomenon of Child Marriage in Iran and the World' (2016) 4(9) International Journal of Paediatrics 3499.

197 Justice for Iran, 'Early and Forced Marriages in the Islamic Republic of Iran. A Brief Submitted to the Office of the High Commissioner for Women's Rights and Gender Section (WRGS) for the 26th session of the Human Rights Council' (December 2013): <http:// www.wluml.org/sites/wluml.org/files/Early\%2oand\%2oForced\%2oMarriages\%2oin\%2o the\%2OIRI.pdf $>2$.

Ibid 1. 
body in Turkey held that girls' age of consenting to marriage should be nine. ${ }^{199}$ Parliament rejected this recommendation, but clearly the opinion that marrying a nine-year-old should be legal, is common enough to be suggested to the legislator. And that is a political matter.

\subsection{Applying Blasphemy Laws to Prevent Violence}

The judgment in $E S \mathcal{v}$ Austria has been harshly criticised. Besides expressing doubts about balancing religious feelings against free speech, and the reasoning in finding the applicant's statement untrue, academics have criticised the ECtHR for relying heavily on the speaker's intent; ${ }^{200}$ for applying the value judgment doctrine; ${ }^{201}$ for claiming 'justified indignation' in Muslims although no Muslim had complained;202 for reinforcing blasphemy laws while the European trend is towards repealing them; ${ }^{203}$ and for supporting an extreme interpretation of Islam. ${ }^{204}$

The fact that the ECtHR referred to articles of law, reports and recommendations on hate speech supports the interpretation that its holdings in $E S v$ Austria are coloured by the fact that the applicant was speaking under the auspices of a racist, Nazi-rooted party. Presumably she was motivated by hatred. However, under the ICCPR, the right to opinion includes that ' $\mathrm{n}] \mathrm{o}$ person may be subject to the impairment of any rights under the Covenant on the basis of his or her actual, perceived or supposed opinions. ${ }^{.05}$ Es's discourse, taken at

199 'Anger in Turkey Over Child Marriage Comments' BBC News, 3 January 2018: <https://www. bbc.co.uk/news/world-europe-42558328>.

200 E Bougiakiotis, ' $E S$ v Austria: Blasphemy Laws and the Double Standards of the European Court of Human Rights', (UK Constitutional Law Association, 22 November 2018): <https:// ukconstitutionallaw.org/2018/11/22/emmanouil-bougiakiotis-e-s-v-austria-blasphemylaws-and-the-double-standards-of-the-european-court-of-human-rights/>.

201 Smet (n 190).

202 M Milanovic, 'Legitimizing Blasphemy Laws Through the Backdoor: The European Court's Judgment in ES v Austria' (EJIL:Talk!, 29 October 2018): <https://www.ejiltalk.org/ legitimizing-blasphemy-laws-through-the-backdoor-the-european-courts-judgment-in-es-v-austria/>.

203 G Puppnick provides a good overview of the European trend towards abolishing blasphemy law in his 'Written Observations in the Case of E.S. v. Austria (Application No 38450/12)': $<$ https://eclj.org/free-speech/echr/observations-ecrites-en-tierce-intervention>. This piece was written before the ruling in $E S$, but the author has criticised the Court on the same grounds in interviews after the ruling.

204 M Scott, 'The ECtHR Has not Created a European Blasphemy Law but it Has Produced a Lamentable Judgment' (Barrister Blogger, 27 October 2018): <http://barristerblogger. com/2018/10/27/the-ecthr-has-not-created-a-european-blasphemy-law-but-it-hasproduced-a-lamentable-judgment>. 
face value, was aimed at religious doctrines, not Muslims as a group and it is a judicial principle that defendants must be convicted on the correct grounds, and presumed innocent.

Convicting Sabaditsch-Wolff for incitement could not have been justified. Instead, she was found guilty of expression that might arouse justified indignation. But the rulings, including Strasbourg's, do not hold up to scrutiny. It cannot be convincingly argued that the impugned statement had no factual basis. Both the context and venue of the speech was political. As there is no way of expressing the opinion that the Prophet's relationship with his child bride is inexcusable, without risking upsetting Muslims, penalising Es's wording amounts to a blanket ban on criticising Muhammad's relationship with Aisha. Muslims' presumed indignation cannot be justified on grounds of context, venue, manner or lack of factual basis. So why were Austria's arguments upheld at Strasbourg?

Was the other major risk factor to religious peace, indignation (justified or not) an underlying reason for the domestic rulings? Did the Austrian Judges remember the cartoon affairs in Denmark and France and assume that Sabaditsch-Wolff's blasphemous statements might spur violent reaction from Islamic extremists even if their wrath could not be justified? Just like in Otto-Preminger, the state's interference might possibly have been justified, under Article 10(2) of the Convention, not by the rights of others, but by 'public safety' or 'the prevention of disorder or crime'. But the Austrian state did not mention any such hazard. Neither did the ECtHR. Had such reasons been given, it would surely have been interpreted as the endorsement of protecting religious peace by granting criminals the heckler's veto on acceptable criticism of religion. But at least that premise would have been reasonable. Muslims' alleged right, to silence those who point out that having sex with a child is called paedophilia, is not.

The case of $E S v$ Austria raises great concerns about the future of free speech in Europe. Religious hatred may well be an underlying reason for why the applicant chose to link the story of Muhammad and Aisha to child marriages in our times, but she was not convicted of incitement. The impugned statements were made in a political context and should thus deserve great protection under the Convention. Apparently, the domestic courts were trying to do either or both: protect Muslims from religious hatred by applying blasphemy law - or prevent violent outburst among Muslims - by giving into their 
presumed sensitivities. Without even mentioning these two obvious threats to public order, the ECtHR deferred to the state, relying on the alleged right to respect for religious feelings.

Does the ECtHR's approach to protection of religious peace jeopardise freedom of expression in Europe?

Sadly, the answer is yes: the Court is gradually broadening the interpretation of the rights of others under Article 10(2). In balancing freedom of expression against religious freedom, the ECtHR is facing a dilemma that stems first and foremost from its own initiative in granting the protection of religious feelings the status of a human right. Such a right is not mentioned in the Convention and did not exist in Europe as a personal right before the drafting of the ECHR. The ruling in $E S$ may have a chilling effect whenever religious doctrines collide with contemporary values. Topics like child marriages and female genital mutilation, justified by culture and faith, male circumcision as a ritual in Judaism and Islam, oppression of women justified by religious principle, and many other social matters that have some relation to religion, must be addressed in a democratic society. Furthermore, since Article 9 covers not only religion but other life philosophies as well, the right not to be offended may eventually be interpreted as a general right. The 'headscarves cases' indicate that the Court may be on the road to recognising the right to respect for secular feelings.

Less than half of the ECHR's member states consider religious insults a criminal offence and the European trend is towards the abolition of blasphemy law. Even if the Court accepts restrictions on freedom of expression, intended to protect religious feelings, it has not, so far, imposed such an obligation. However, the doctrine of 'gratuitously offensive expression' seems inconsistent with various European bodies' concerns about sanctions against blasphemy and opens a gateway to the criminalisation of political criticism. It must be revised.

In order to fulfil its role as a protector of freedom of expression, the ECtHR must revise its approach to religious insults. My recommendations are the following:

1. The use of the term 'justified indignation' should be reconsidered, as under the tule of law individuals are responsible for their reactions to their own hurt feelings. Indignation does not justify violence.

2. The ECHR does not include a right not to be offended. In a democratic society, offended citizens must deal with their justified indignation in the political and social context by exercising their freedom of speech, not by silencing their offenders. The same should apply to those whose religious feelings are offended. 
3. The term 'religious peace' should be interpreted as absence of violent conflict. If a state claims that expression on religion, or any ideology, poses a threat to religious peace or public order, it should be required to demonstrate imminent uproar, too severe for the authorities to control and prosecute offenders.

4. If religious symbols are used to incite hatred, the incitement must be addressed, not the symbol. Muslims have a right, under Article 9, to manifest their legally recognised religion by symbols that may be offensive to non-Muslims.

5. Restricting Islamic proselytism in the name of 'peaceful coexistence' must be reconsidered. Treating resentment towards Western values in the same way as blasphemy has been treated through the ages has no grounds in the Convention. Islamists have the right to despise Western civilisation; that is a political opinion, protected under Article 10, which furthermore grants them the right to express that view, provided, of course, that the expression does not incite hatred.

6. Religious hatred should normally be addressed in the political arena. This applies equally to those who oppose immigration and those who promote Islamism. When hatred must be addressed by the justice system, it should be done by applying laws that cover incitement to hatred, not blasphemy laws.

The justification for establishing a right to respect for religious feelings under Article 9 is that religious peace must be preserved. Yet, no blasphemy case tried at Strasbourg so far indicates that any risk of violent conflict was imminent. The concept 'religious peace' is virtually meaningless under Strasbourg's jurisprudence. Apparently, it just means that no religious group is angry, and the likelihood of indignation counts as 'a pressing social need' to suppress fundamental freedoms. If such a pressing need is apparent, the grounds for curbing free speech should be public safety or prevention of crime - not religious feelings. 